\title{
Psikolojik Yardım Almanın Dini / Manevi Açıdan Damgalanması ve Bu Süreci Yaşayanların Manevi Danışmanlık Hizmetlerinden Beklentileri*
}

\section{The Religious/Spiritual Stigmatization of Receiving Psychological Help, and the Expectations of People Who Go Through this Process from Spiritual Counseling Services**}

\author{
Kevser ÇAĞLAN, Doktora Öğrencisi. \\ İstanbul Üniversitesi, Sosyal Bilimler Enstitüsü, Türkiye. \\ caglankevser@gmail.com \\ http://orcid.org/0000-0002-5638-5013 \\ Gülüşan GÖCEN, Sorumlu Yazar, Doç. Dr. \\ İstanbul Üniversitesi, İlahiyat Fakültesi, Türkiye. \\ gulusan.gocen@istanbul.edu.tr \\ http://orcid.org/0000-0003-4856-9653
}

ISSN: 1303-880X

e-ISSN: 2667-7504

http://ded.dem.org.tr

Makale Türü / Article Type:

Araştırma Makalesi / Research Article

Geliş Tarihi / Received Date: 09.09.2019

Kabul Tarihi / Accepted Date: 26.05.2020

Yayın Tarihi / Published Date: 25.06.2020

Tr/En: $\operatorname{Tr}$

Intihal / Plagiarism: Bu makale, en az iki hakem tarafindan incelendi ve intihal içermediği teyit edildi. / This article has been reviewed by at least two referees and scanned via a plagiarism software.
Atıf/Citation: Çağlan, K. ve Göcen, G. (2020). Psikolojik yardım almanın dini / manevi açıdan damgalanması ve bu süreci yaşayanların manevi danışmanlık hizmetlerinden beklentileri. Değerler Ĕgitimi Dergisi,18(39), s.137-172. https://doi.org/10.34234/ded. 617263

* "Psikolojik hastalıkların yanlış yorumlanması ve inanç eksikliği olarak damgalanması sürecinde manevi destek ihtiyacı" (2019) isimli yüksek lisans tezinden üretilen bu çalışmanın önceki bir versiyonu Sağlık Hizmetlerinde Manevi Danışmanlık ve Rehberlik (Dem Yayınları: 2019) bildiriler kitabında yayınlanmış; Değerler Eğitimi Dergisi'nde hakem görüşleri doğrultusunda yeniden düzenlenmiştir.

** A previous version of this study, which was based on a master thesis titled "The need for spiritual support to challenge the process of misinterpretation of psychological diseases and its stigmatization as a lack of belief" (2019), was published in the book of abstract of Spiritual Counseling and Guidance in Health Services (Dem Publications: 2019); then it was reorganized in line with the opinions of the referee for the publication in the Journal of Values Education. 
Öz: Bu çalışmanın amacı, psikolojik yardım alan dindar bireylerin, yardım almaya yönelik tutumlarının dini inanç ve ibadet hayatlarıyla ilişkisini incelemek, psikolojik yardım alma sürecinde damgalanma yaşayan bireylerin karşılaştıkları problemlere yönelik manevi danışmanlık hizmetinin/rolünün ne olduğunu ortaya koymak ve neler yapabileceğine dair önerilerde bulunmaktır. Nitel metotta olgu bilim deseninde hazırlanan bu çalışmada, amaçlı örnekleme yöntemlerinden kartopu ve maksimum çeşitlilik kullanılmış, farklı psikolojik rahatsızlığa sahip kişiler çalışmaya dâhil edilmiştir. Ölçüt örnekleme de uygulanarak katılımcıların kendilerini dindar olarak tanımlamaları, tanı almış olmaları ve en az iki ay profesyonel psikolojik yardım almış olmaları koşulu sağlanmıştır. Çalışma grubu depresyon, bipolar bozukluk, panik atak, anksiyete ve kişilik bozukluğu tanısına sahip, psikolojik yardım almış ya da almakta olan 1'i erkek 20 kişiden oluşmuştur. Veriler, yarı yapılandırılmış görüşme formu kullanılarak görüşme tekniği ile toplanmış, betimsel analiz kullanılarak yorumlanmıştır. Araştırma sonucunda, yardım almanın kişinin sosyal çevresi tarafından inanç eksikliği olarak damgalanmasının hastalarda içsel damgalanmaya neden olduğu, bu kişilerin tıbbi tedavi almalarının yanında dini uygulamalarındaki eksiklikleri de tespit edip gidermeye çalıştıkları, fakat bu konuda da çeşitli damgalamalara maruz kalabildikleri, hastalıkların doğru şekilde algılanması ve çözümlenmesinde hem hastalar hem de hasta yakınları için manevi desteğe ihtiyaç olduğu belirlenmiştir. Ayrıca yaşadıkları süreç çerçevesinde çevrelerinden almak istedikleri dini ve manevi kaynaklı destekleyici ve incitici olmayan konular sorulmuş ve manevi danışmanlık uygulamalarından neler bekledikleri sunulmuştur.

Anahtar Kelimeler: Psikolojik yardım, Din, Damgalama, Manevi danışmanlık ve rehberlik.

$\&$

Abstract: The aims of this study are to examine religious people who have received psychological help and their attitudes towards receiving psychological help and their religious beliefs and practices, to show what role can the spiritual counseling services take for the problems faced by individuals who are stigmatized in the process of getting psychological help. In this study, which was carried out in qualitative method, people with different psychological illnesses were included using snowball and maximum diversity sampling from purposeful sampling methods. By applying criterion sampling, participants were required to identify themselves as religious, to have been diagnosed and to have received professional psychological help for at least two months. Data were collected by 
interview technique using semi-structured interview form and interpreted using descriptive analysis. As a result of the research it was determined, stigmatization of psychological illnesses as a lack of belief by one's social environment causes internal stigmatization in patients. In addition to condemning receiving medical treatment, patient's religious practices are identified and get corrected. It is observed that there is a need for spiritual support for both patients and their relatives about the right perception and treatment of psychological diseases.

Keywords: Psychological help, Religious, Stigmatization, Spiritual counseling and guidance.

(The Extended Abstract is at the end of the article)

\section{Giriş}

Damgalama, kişinin davranışlarının veya sahip olduğu niteliklerin içinde yaşadığı toplumun normal kabul ettiği ölçülerin dışında sayılması nedeniyle dışlanması, kişiye saygınlığını azaltıcı ve toplumdan ayırıcı yakıştırmalarda bulunulmasıdır (Çam ve Bilge, 2013, s.91; Budak, 2000, s.193). Damga kelimesi Yunanca'da "delik, delmek, yara, leke, iz" (Goffman, 1963, s.1-2) anlamına gelse de, günümüzde sosyal hayat içerisinde kullanılan "damgalama" daha çok "kara leke" anlamındadır (Ayvaışık, Er, Kışlak ve Erkuş, 2000, s.177). Ortaçağ'da suçlu kişilerin, suçluluğun göstergesi olarak bedenlerine kesikler veya yanıklar yoluyla işaretler konulması sözcügün bugünkü anlamına kaynaklık etmektedir (Goffman, 2018, s.27). Türk Dil Kurumu Sözlügü’ne bakıldığında mecazi anlamıyla "bir kimsenin adını kötüye çıkaran, yüz kızartıcı durum" olarak tanımlanan damga, "bir şeyin üzerine; belirlemek, ayırt etmek için işaret yapmak, damga vurmak, bir kimseye; gerçeğe dayanmadan olumsuz anlamda herhangi bir özellik veya nitelik yüklemek, birine yüz kızartıcı bir suç yüklemek" (TDK, 2018) olarak açıklanmaktadır. Türkçe literatürde de kullanılan damgalamanın İngilizce'deki karşılığı olan "stigma” kelimesi, "mimlemek, dağlanarak yapılan iz" (Reber, 1985, s.731), "utanç verici bir şeyin başkaları üzerinde yarattığı etki, leke, tepecik, dişicik başı, gözenek (İz, Hony ve Aldersan, 1989, s.521) kusur, damga, dağlama izi gibi anlamlara gelmektedir.

Damgalama, (İngilizce'deki karşılı̆ğ ve zaman zaman Türkçe'de de kullanılan "stigmatization"), kişi ile değer kaybı ilişkisi üzerinden incelenir. Bu nedenle sosyal psikoloji alanında çokça ele alınmış bir olgu olsa da, günümüz- 
de sağlık ile ilgili konularda daha çok öne çıktığı görülmektedir. Literatürde damgalamanın kaynağ çeşitli faktörlerle bir arada değerlendirilerek irdelenmiş, bunun sonucunda içselleştirilmiş damgalama ve toplumsal damgalama olarak iki farklı boyutta ele alınmıştır (Baysan- Arabacı, Yedikardaşlar- Başoğul ve Büyükbayram, 2015, s.114-115; Sezer ve Gülleroğlu, 2016).

Toplumsal damgalanma, bazı gruplar/ kişiler hakkında önceden edinilmiş olan toplumsal değer yargıları, kalıp yargılar ve sterotipler yoluyla ortaya çıkan tutum ve davranışlardır. Önyargılar, damgalamaya konu olan grup ve kişilere tepkisel yaklaşılmasına, onların toplum içinde sosyal ve psikolojik olarak dışlanmalarına neden olmaktadır (Vogel, Wade ve Haake, 2006; Vogel, Wade ve Hackler, 2007; Vogel, Wade ve Ascheman, 2009). İçselleştirilmiş damgalama ise, bireyin kendi adına bazı olumsuz basmakalıp düşünceleri kabul etmesi sonucu ortaya çıkan değersizlik, utanç hissi ve gizlenme davranışıdır (Sezer ve Gülleroğlu, 2016: s.78). Kişi içsel damgalamada, kendini etiketlenmiş hissederken; toplumsal damgalanmada çevresiyle etkileşime girer ve etiketlenme davranışına maruz kalır (Ersoy ve Varan, 2007). Yapılan araştırmalarda, toplumsal damgalamanın içsel damgalamayı yordadığına toplumsal damgalama düzeyinin içselleştirilmiş damgalama düzeyindeki artış ve azalmaya etki ettiğine ilişkin bulgular vardır (Doğanavşargil, 2009; Vogel, Bitman, Hammer ve Wade, 2013).

İçsel damgalanma, "psikolojik bozukluğu olan kişilerin etiketlenme, dişlanma ve ayrımcılık yaşayarak olumsuz değerlendirileceğine iliş̧kin duyduğu korku" olarak da tanımlanabilir (Topkaya, 2014, s.472). Nitekim psikolojik bozukluğu nedeniyle içselleştirilmiş damgalanma yaşayan bireyler, toplumda ayrımcılığa maruz kalmasalar bile kendilerini damgalanmış olarak hissetmektedir. Bu durum bireylerde hastalık semptomlarını kötüleştirmekte ve iyileşmeyi yavaşlatmaktadır (Kapıkıran ve Kapıkıran, 2016; Gökengin, Çalık ve Öktem, 2017). İçsel damgalanma bireyin düşük özsaygıya sahip olmasıyla ilişkilendirilebileceği gibi çocukluğundan itibaren edindiği kültürel imgeler ve olumsuz değerlendirmeler de bu tutuma kaynaklık edebilmektedir (Link, Struening, Neese-Todd, Asmussen ve Phelan, 2001; Batinic, Lemonis ve Opacic, 2013). Ne var ki erken çağlardan bu yana damgalama ve ayrımcılığa en fazla maruz kalan kesim psikolojik bozukluğu olan kişilerdir.

Psikolojik bozukluklar geçmişten bu yana insanları korkutmaya, tedirginlik yaratan bir durum olmaya devam etmiş, psikolojik bozuklukların tamamı damgalamaya konu olmuştur. Bu konudaki olumsuz basmakalıp yargılar, psikolojik tedavi almış kişilerin yaşam alanlarının daraltılmasına, rahatsızlıkları bulaşıcı, 
tedavi edilemez olarak algılanmasına neden olmuş, onlarla evlilik yapılamayacağı, herhangi bir yerde çalışamayacakları ve sürekli muhtaç yaşayacaklarının düşünülmesi toplum içerisinde örselenmelerine yol açmıştır (Hayward, Wong ve Lam, 2002; Yüksel ve Taşkın, 2005).

Psikolojik yardım almanın damgalanması üzerine gerek yurt içinde gerekse yurtdışında birçok çalışma yürütülmüştür (Eker, Öner ve Şahin, 2010; Oban ve Küçük, 2011; Vogel ve ark. 2013; Gargari 2015). Hastalar, hasta yakınları, sağlık çalışanları, hemşireler, tıp ve ilahiyat öğrencileri üzerine yapılan bu çalışmalar, hastalara ve psikolojik sağlığa yönelik alg1 ve tutumların incelendiği çoğu nicel modelde yapılmış saha araştırmalarıdır. Hekimler sağlı servislerine başvurarak psikolojik yardım alan kişilerin taşıdıkları fiziksel semptomlara şüpheyle yaklaşmakta, bu belirtileri göz ardı ederek doğrudan psikosomatik bozukluk adı altında değerlendirmektedirler (Kuş-Saillard, 2010). Ben-Porath (2002) tarafından yapılan senaryoya dayalı bir araştırmada da fiziksel rahatsızlıkları nedeniyle yardım alan kişiler ile psikolojik bozukluğu nedeniyle yardım alanlar karşılaştııılmıştır. Psikolojik yardım alan kişilerin daha sık duygusal dalgalanmalar yaşadıkları, kendilerine olan güvenlerinin ise daha düşük olduğu görülmüştür.

Psikolojik bozukluğu olan kişilere toplumda korku ve huzursuzluk yarattıkları ön kabulü ile etiketleme, dışlama ve ayrımcılık yapılmasının temelinde birçok faktör bulunmaktadır. Sosyo-demografik değişkenler, kültür, hastalıklar konusundaki bilgi eksikliği ve dini inançlar bunlardan bazılarıdır. Damgalayıcı tutumu tetikleyen demografik özelliklerden en önemlisi, sosyal sınıftır. Düşük sosyal s1nıfa ait olan bireyler damgalanma ve dışlanmayla daha çok karşılaşmaktadırlar. Kentlerden gelen hasta ve hasta yakınları, köy veya kırsal kesimden gelen hastalara göre daha çok kabul görmektedirler (Taşkın, 2007). Bunun yanı sıra araştırmalarda daha genç olanların, yaş almış kişilere göre ve kadınların erkeklere göre daha az damgalayıcı olduğu tespit edilmiştir (Kaya ve Ünal, 2006; Bilge ve Çam, 2010). Ayrıca hastalıkların belirtileri, sebepleri, normal ve anormal davranışların belirlenmesi ve bu davranışların ne derece hastalık olarak ifade edildiği içinde bulunulan kültüre göre farkl1lık göstermektedir (Eker, 1989). Örneğin Doğu toplumlarında hastalıkların tedavisi için geleneksel iyileştirici unsurların kullanımının ve tıp dışı yardım arama davranışlarının daha yaygın olduğu görülmektedir. Öte yandan farklı inanç sistemleri, kültürler ve tarihsel olaylar psikolojik bozukluklara karşı tutum ve davranışın yönünü etkilemektedir.

Fiziksel hastalıklarda olduğu gibi psikolojik hastalıkların etiyolojisi üzerinde de kültürel ve dini tutumlar etkili olmuştur. Hangi din olduğunun önemi olmak- 
sızın, katı bir din inancının varlığı, hastalıkların sebebini metafiziksel olarak açıklamaya ve bu kişilere yönelik sert ve yargılayıcı bir yaklaşıma sebep olmuştur (Babaoğlu, 2002; Geçtan, 2012). Örneğin tarihte cüzzam, Tanrı'nın insana verdiği bir kötülük, veba Tanrı'nın insanlara günahkâr davranışları yüzünden verdiği ceza, AIDS ilahi bir ceza ve AIDS'e yakalananlar ise günahkârlar olarak yorumlanmıştır (Oran ve Şenuzun, 2008; Çam ve Uğuryol, 2019). Benzer biçimde Antik Yunan'da ve Ortaçağ'da da psikolojik hastalıkların kişiler için hak edilmiş bir ceza, şeytan veya cin çarpması olarak ve büyü ile ilişkilendirilerek açıklandığı görülmektedir (Foucault, 2013). Stanford (2007) tarafından yapılan bir araştırmada da din görevlilerinin tarihtekine benzer biçimde psikolojik bozuklukları kişilerin işledikleri günahların bir sonucu olarak değerlendirdikleri ifade edilmektedir.

Psikolojik yardım alma sürecindeki kişilere "deli, hasta" vb. yakıştırmaların yapılması, onların sosyal yaşamlarında ve kendi içlerinde çatışmalara sebebiyet vermektedir. Dindar çevrelerde bunlara ek olarak "inancı eksik, imanı azalmış, tevekkülsüz" gibi kişinin dini ve manevi duygularına ilişkin yargılamaların da olduğu görülür. Hz. Peygamberin de risaletin ilk yıllarında "mecnun" olarak isimlendirilip bulunduğu toplum tarafından ötelenmiş ve toplumdan tecrit edilmeye çalışıldığı bilinmektedir (Kalem, 68/51; Tekvir, 81/22). Bu şekilde özellikle İslam dini üzerinden konuşulursa din, kalpleri açık beyan bildiğini söyleyen bir Allah tasavvurudur ve kişilerde hem içsel hem de sosyal damgalanmalara yol açtığını iddia etmek makul değildir. Din üzerinden yapılan damgalamalar, dinin asli metinlerinden olmaktan ziyade daha çok dinin doğru yorumlanmamasından kaynaklıdır demek mümkündür. Yaşamdaki sıkıntılar ve çözülmesi gereken problemler, dindar insan açısından hayata geliş amacını deneyimlemek olarak değerlendirilmektedir (Kula, 2005; Ayten, 2010; Göcen, 2015). Aynı şekilde hastalıklar ve damgalanma da dindar insan için birer tecrübe ve imtihandır. Nasıl ki yardım alıyor olmak bir cezalandırılma değilse, psikolojik hastalıklara yakalanma sebebi de dini/ manevi eksiklik veya yoksunluktan kaynaklanıyor değildir. Dünyada hiçbir insan bir diğerine benzemediği gibi, yaşanan hiçbir olayın arkasındaki mana tam olarak genellemez, kişiden kişiye değişen yönleri vardır.

Türk toplumunu ele alan literatürü incelediğimizde ülkemizdeki dini tutumlar ve yaşantılar ile damgalama ilişkisi üzerine sayılı çalışma olduğu görülmektedir (Al-Krenawi 2005; Diaz, Neilands Rivera ve Betancourt 2010; Eker ve ark. 2010; Güngörmüş, Ekinci ve Daş, 2014). Bu çalışma, dini/manevi yaşam ile 
damgalama ilişkisini doğrudan ele almasının yanı sıra, din temelli açıklamaların bir damgalama çeşidi olduğunu ve bireyde içsel damgalamaya neden olduğunu, dini inanç ve yaşantıların psikolojik yardım alma sürecindeki etkilerini, ortaya koyan ilk araştırma olması bakımından son derece özgündür. Din ve psikoloji ilişkisi bağlamında güncel bir problemi inceleyen bu çalışma, problemin çözümünde manevi danışmanlık ve rehberlik hizmetinin rolünü de ele alması bakımından önemlidir. Böylece araştırma, a) Psikolojik hastalığa sahip bireyler kendilerini dini açıdan nasıl değerlendirmektedir? b) Bireylerin yardım alma sürecinde aile ve sosyal çevrelerinde karşılaştıkları dini/ manevi temelli açıklama ve öneriler nelerdir? c) Bu kişiler psikolojik yardım alma sürecinde manevi danışmanlık hizmetini nasıl değerlendirmektedir ve onun rolüne dair görüşleri nelerdir? soruları etrafinda şekillendirilmiştir.

\section{Yöntem}

\section{Araştırmanın Modeli}

Bu çalışmada, psikolojik destek alan kişilerin ve onlara tanıklık eden yakınlarının neler hissettikleri ve bu süreçten nasıl etkilendiklerini derinlemesine anlayabilmek ve manevi danışmanlık hizmeti sunan uzmanlara sağlıklı öneriler sunabilmek için nitel araştırma yöntemi tercih edilmiş, araştırma desenlerinden olgu bilim modeli kullanılmıştır. Araştırmada amaçlı örnekleme yöntemlerinden kartopu, maksimum çeşitlilik ve ölçüt örnekleme kullanılmıştır. Buna göre katılımcıların psikolojik destek almak için psikoloğa veya tedavi almak için psikiyatra giderek tanı almış olması, bununla birlikte en az iki ay profesyonel psikolojik yardım almış olması ve kendilerini dindar olarak tanımlaması ölçüt alınmıştır.

\section{Araştırmanın Çalışma Grubu}

Katılımcılar, 20-54 yaş aralığında $(X=26,65)$ olup biri erkek on dokuzu kadın toplam 20 kişiden oluşmaktadır. Kadınların büyük çoğunluk olduğu bir çalışma grubu oluşmuştur. Planlı bir tercih olmamakla birlikte kartopu örnekleme çerçevesinde erkek katılımcılara ulaşım daha az olmuştur. Katılımcıların 3'ü ilkokul, 3'ü lise, 1'i ön lisans, 11'i lisans, 2'si yüksek lisans mezunu kişilerdir. Çalışma grubu ağırlıklı olarak lisans eğitimi almış öğrenim düzeyi yüksek kişilerden oluşmaktadır. Katılımcıların 3'ü öğretmenlik, 2'si danışma ve yönlendir- 
me, 1'i satış danışmanlığı, 1'i de ayakkabı imalatı ve satışı yapmakta olup 7'si çalışmaktadır. Geneli orta ekonomik düzeye sahip olduğunu belirten çalışma grubunun medeni durumlarına bakıldığında, 5'nin evli, 2'nin nişanlı ve 13'nün bekâr olduğu görülmektedir. Katılımcilardan, 5'i panik atak, 3'ü yaygın anksiyete, 2'si bipolar, 1'i somatik bozukluk, 1'i kişilik bozukluğu, 2'si sosyal fobi, 2'si depresyon teşhisi almış olup, 4'ü rahatsızlığını isimlendirmek istemeyerek sadece psikolojik yardım aldığını belirtmiştir. Gönüllü olarak dahil olan katılımcıların tamamı Müslüman olduklarını belirtmişlerdir. 14'ünün tedavisi halen devam etmekte olup, diğer 6'sı tedavisinin tamamlandığını belirtmişlerdir.

Tablo 1: Çalışma Grubuna Ait Bilgiler

\begin{tabular}{|c|c|c|c|c|c|c|c|c|c|c|}
\hline そ) & $\underset{\nearrow}{\mathbb{\tau}}$ & 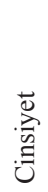 & 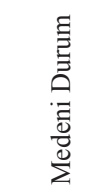 & 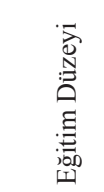 & 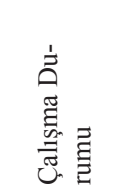 & 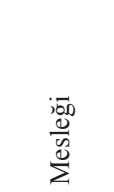 & 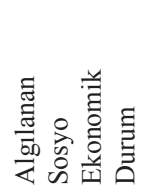 & 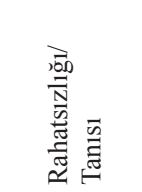 & 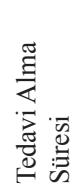 & 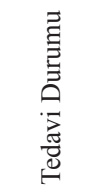 \\
\hline K1 & 47 & $\mathrm{~K}$ & Evli & Lise & $\begin{array}{l}\text { Çalışmı- } \\
\text { yor }\end{array}$ & - & Orta & Panik Atak & 4 y1l & $\begin{array}{l}\text { Ta- } \\
\text { mam- } \\
\text { landi }\end{array}$ \\
\hline K2 & 26 & $\mathrm{~K}$ & Bekar & Lisans & $\begin{array}{l}\text { Çalışmı- } \\
\text { yor }\end{array}$ & - & Orta & Depresyon & $1 \mathrm{y} 11$ & $\begin{array}{l}\text { Devam } \\
\text { Ediyor }\end{array}$ \\
\hline K3 & 24 & $\mathrm{~K}$ & Bekar & Lisans & Çalışıyor & $\begin{array}{l}\text { Din } \\
\text { Kültürü } \\
\text { Öğret- } \\
\text { meni }\end{array}$ & Orta & $\begin{array}{l}\text { Sosyal } \\
\text { Fobi- Ago- } \\
\text { rafobi }\end{array}$ & 2 y1l & $\begin{array}{l}\text { Ta- } \\
\text { mam- } \\
\text { land1 }\end{array}$ \\
\hline K4 & 44 & $\mathrm{~K}$ & $\begin{array}{l}\text { Bekar- } \\
\text { Boşan- } \\
\text { mış }\end{array}$ & $\begin{array}{l}\text { Ön } \\
\text { Lisans }\end{array}$ & Çalışıyor & $\begin{array}{l}\text { Din } \\
\text { Kültürü } \\
\text { Öğret- } \\
\text { meni }\end{array}$ & İyi & $\begin{array}{l}\text { Kişilik } \\
\text { Bozukluğu }\end{array}$ & 4 y1l & $\begin{array}{l}\text { Devam } \\
\text { ediyor }\end{array}$ \\
\hline K5 & 22 & $\mathrm{~K}$ & Bekar & Lisans & $\begin{array}{l}\text { Çalışm1- } \\
\text { yor }\end{array}$ & Öğrenci & Orta & $\begin{array}{l}\text { Bipolar } \\
\text { Bozukluk }\end{array}$ & 3 y1l & $\begin{array}{l}\text { Devam } \\
\text { ediyor }\end{array}$ \\
\hline K6 & 25 & $\mathrm{~K}$ & Bekar & $\begin{array}{l}\text { Yüksek } \\
\text { Lisans }\end{array}$ & $\begin{array}{l}\text { Çalışm1- } \\
\text { yor }\end{array}$ & - & Orta & Psikoterapi & $\begin{array}{l}2,5 \\
\text { ay }\end{array}$ & $\begin{array}{l}\text { Devam } \\
\text { ediyor }\end{array}$ \\
\hline K7 & 25 & $\mathrm{~K}$ & Bekar & $\begin{array}{l}\text { Yüksek } \\
\text { Lisans }\end{array}$ & Çalışıyor & Eğitmen & $\begin{array}{l}\text { Ortanin } \\
\text { altı }\end{array}$ & $\begin{array}{l}\text { Kayg1 } \\
\text { Bozukluğu }\end{array}$ & $6 \mathrm{y} 11$ & $\begin{array}{l}\text { Devam } \\
\text { ediyor }\end{array}$ \\
\hline K8 & 21 & $\mathrm{~K}$ & Bekar & Lisans & $\begin{array}{l}\text { Çalışmı- } \\
\text { yor }\end{array}$ & Öğrenci & Orta & Psikoterepi & $1 \mathrm{y} 11$ & $\begin{array}{l}\text { Devam } \\
\text { ediyor }\end{array}$ \\
\hline K9 & 24 & $\mathrm{~K}$ & Bekar & Lisans & Çalışıyor & $\begin{array}{l}\text { Din } \\
\text { Kültürü } \\
\text { Öğret- } \\
\text { meni }\end{array}$ & Orta & $\begin{array}{l}\text { Panik } \\
\text { Atak, } \\
\text { OKB, } \\
\text { Kayg1 } \\
\text { Bozukluğu }\end{array}$ & 8 y1l & $\begin{array}{l}\text { Devam } \\
\text { ediyor }\end{array}$ \\
\hline K10 & 50 & $\mathrm{~K}$ & Evli & İlkokul & Emekli & Tekstil & İyi & $\begin{array}{l}\text { Bipolar } \\
\text { Bozukluk }\end{array}$ & $19 \mathrm{y} 1 \mathrm{l}$ & $\begin{array}{l}\text { Devam } \\
\text { ediyor }\end{array}$ \\
\hline K11 & 51 & $\mathrm{~K}$ & $\begin{array}{l}\text { Bekar- } \\
\text { Boşan- } \\
\text { miş }\end{array}$ & İlkokul & $\begin{array}{l}\text { Çalışmı- } \\
\text { yor }\end{array}$ & - & Orta & $\begin{array}{l}\text { Panik } \\
\text { Atak, Dep- } \\
\text { resyon }\end{array}$ & 9 ay & $\begin{array}{l}\text { Ta- } \\
\text { mam- } \\
\text { landi }\end{array}$ \\
\hline K12 & 23 & $\mathrm{~K}$ & Bekar & Lisans & $\begin{array}{l}\text { Çalışm1- } \\
\text { yor }\end{array}$ & Öğrenci & Orta & Psikoterapi & $\begin{array}{l}2,5 \\
\text { ay }\end{array}$ & $\begin{array}{l}\text { Devam } \\
\text { ediyor }\end{array}$ \\
\hline
\end{tabular}




\begin{tabular}{|c|c|c|c|c|c|c|c|c|c|c|}
\hline K13 & 23 & K & Nişanlı & Lisans & $\begin{array}{l}\text { Çalışm1- } \\
\text { yor }\end{array}$ & - & İyi & Psikoterapi & $6 \mathrm{y} 1 \mathrm{l}$ & $\begin{array}{l}\text { Ta- } \\
\text { mam- } \\
\text { land1 }\end{array}$ \\
\hline K14 & 30 & K & Evli & Lisans & $\begin{array}{l}\text { Çalışmı- } \\
\text { yor }\end{array}$ & - & Orta & $\begin{array}{l}\text { Kayg1 } \\
\text { Bozukluğu }\end{array}$ & $\begin{array}{l}1,5 \\
\mathrm{y} 11\end{array}$ & $\begin{array}{l}\text { Ta- } \\
\text { mam- } \\
\text { land1 }\end{array}$ \\
\hline K15 & 54 & E & Evli & İlkokul & Çalışıyor & $\begin{array}{l}\text { Ayak- } \\
\text { kab1 } \\
\text { İmalat- } \\
\text { Satış }\end{array}$ & Orta & Panik Atak & 2 yil & $\begin{array}{l}\text { Ta- } \\
\text { mam- } \\
\text { landı }\end{array}$ \\
\hline K16 & 20 & K & Bekar & Lisans & Çalışıyor & $\begin{array}{l}\text { Satış } \\
\text { Danış- } \\
\text { manı }\end{array}$ & Orta & $\begin{array}{l}\text { Psiko- } \\
\text { somatik } \\
\text { Bozukluk }\end{array}$ & 8 ay & $\begin{array}{l}\text { Devam } \\
\text { ediyor }\end{array}$ \\
\hline K17 & 24 & K & Bekar & Lisans & $\begin{array}{l}\text { Çalışm1- } \\
\text { yor }\end{array}$ & - & Orta & Depresyon & $\begin{array}{l}2,5 \\
\text { y1l }\end{array}$ & $\begin{array}{l}\text { Devam } \\
\text { ediyor }\end{array}$ \\
\hline K18 & 38 & K & $\begin{array}{l}\text { Bekar- } \\
\text { Boşan- } \\
\text { mış }\end{array}$ & Lise & Çalışıyor & $\begin{array}{l}\text { Danış- } \\
\text { ma- } \\
\text { Yönlen- } \\
\text { dirme }\end{array}$ & Orta & Panik Atak & $10 \mathrm{y} 1 \mathrm{l}$ & $\begin{array}{l}\text { Devam } \\
\text { ediyor }\end{array}$ \\
\hline K19 & 40 & K & Nişanlı & Lise & Çalışıyor & $\begin{array}{l}\text { Danış- } \\
\text { ma- } \\
\text { Yönlen- } \\
\text { dirme }\end{array}$ & Zayif & $\begin{array}{l}\text { Kaygı } \\
\text { Bozukluğu }\end{array}$ & 3 yil & $\begin{array}{l}\text { Devam } \\
\text { ediyor }\end{array}$ \\
\hline K20 & 23 & K & Bekar & Lisans & $\begin{array}{l}\text { Çalışm1- } \\
\text { yor }\end{array}$ & - & $\begin{array}{l}\text { Ortanin } \\
\text { altı }\end{array}$ & $\begin{array}{l}\text { Sosyal } \\
\text { Fobi }\end{array}$ & $\begin{array}{l}1,5 \\
\text { y1l }\end{array}$ & $\begin{array}{l}\text { Devam } \\
\text { ediyor }\end{array}$ \\
\hline
\end{tabular}

\section{Veri Toplama Aracının Oluşturulması}

Psikolojik rahatsızlıkların dindarlar tarafından dini yaşamın zayıflığı olarak görülüp görülmediği, bunun kişinin yaşamında içsel ve toplumsal damgalanma olarak nasıl yaşandığı görüşmeler yoluyla tespit edilmeye çalışılmıştır. Görüşme formunda öncelikle çalışma hakkında kısa bir bilgi verilmiş, bu bilgiler kişinin konuyu anlamasına yardımcı olacak şekilde yalın bir dille anlatılmıştır. Devamında katılımcıları tanımaya yönelik kişisel bilgi formu eklenmiştir. Sorular yarı-yapılandırılmış şekilde, katılımcıların anlayabileceği düzeyde ve açık ifadelerle yazılmıştır. Görüşme formu oluşturulduktan sonra soruların geçerliliğini, içerik ve yapı bakımından değerlendirilmesini sağlamak amacıyla form iki akademisyen ve bir psikoloğun takdirine sunulmuştur. Din psikolojisi alanında uzman iki akademisyene ulaşılmış, soruları değerlendirmeleri istenmiş, onlardan gelen öneriler çerçevesinde sorular tekrar gözden geçirilmiştir. Aynı zamanda hali hazırda danışanlarıyla terapi yapan bir klinik psikolog ile de yüz yüze görüşülerek sorular üzerinden birlikte geçilmiştir. Uzmanlardan gelen görüş ve öneriler doğrultusunda görüşme soruları yeniden düzenlenmiştir. İki kişi ile ön görüşme yapılarak soruların uygulanabilirliği test edilmiş, görüşme formunun son haline ulaşılmıştır. 


\section{Verilerin Toplanma ve Analiz Süreci}

Veriler, 2019 yılı Nisan ayında toplanmıştır. Tedavisi tamamlanan ya da devam etmekte olan ve bunun yanı sıra ilaç tedavisi veya psikoterapi alan kişilere göre soruların sorulma şekli değişiklik göstermiştir. Görüşmeler sırasında konuşmalar kayıt altına alınmış, daha sonra yazıya aktarılarak çözümlemesi yapılmıştır. Bir kişi sesinin kaydedilmesine izin vermemiştir. Elde edilen veriler betimsel analize tabi tutulmuştur. Buna göre yanıtlar, oluşturduğu temalara göre taslak temalar altında birleştirilerek kategorilere ayrılmıştır. Daha sonra verilen yanıtlardan yola çıkılarak alt temalar oluşturulmuş, yanıtlar sınıflandırılmıştır. Bunun yanında katılımcıların yanıtlarının kullanılabileceğine dair izin belgeleri, görüşmelerin kayıtları ve deşifreleri araştırmacı tarafından korunmuştur. Katılımcıların her birine numara verilerek çalışmada isim yerine katılımcı numaraları ile rol almaları sağlanarak kimlikleri gizli tutulmuştur. Ayrıntılı betimlemenin yanında doğrudan alıntılara sık sık yer verilmeye çalışılmıştır. Bulgular araştırmacıların gözlemleri ile desteklenerek yorumlanmıştır.

\section{Araştırmacıların Rolü}

Nitel araştırmada araştırmacı da bir aktördür ve kendisini gözlemler. Araştırmacılardan biri, soruların incelenmesi için uzman görüşü alınacak psikoloğu ziyaret etmek üzere randevu alarak çalıştığı hastaneye gittiğinde kendisinde damgalanma korkusu olduğunu hissetmiştir. Psikoloğun odasına girdiğinde psikoterapi almak için gelmemiş olmasına rağmen dışarıda onu gören insanlar tarafindan damgalanma korkusu yaşamıştır. Diğer araştırmacı da bir seminer vermek için cezaevine gittiği sırada yol tarifi sorduğu kişilerin sorgulayıcı bakışları karşısında benzer biçimde damgalanma korkusu yaşamıştır. İki araştırmacı da ötekileştirilmenin az da olsa neler hissettirebileceğini deneyimlemişlerdir.

\section{Bulgular ve Yorumlar}

\section{Psikolojik Yardım Almış ya da Almakta Olan Dindar Danışanların, Psikolojik Yardım Alma Sürecinde Dini/Manevi Açıdan Karşılaş- tıkları Toplumsal Damgalanmaya Dair Görüşleri}

Katılımcılara, "psikolojik yardım alma durumlarının ortaya çıkma sebebinin ne olduğu" ile ilgili sosyal çevreleri tarafından özellikle inanç veya dini yaşantılarıyla ilgili açıklama ve yönlendirmeler olup olmadığı sorulmuştur. Buna ceva- 
ben katılımcılarımızın neredeyse tamamı, bu tür genel basmakalıp, olumsuz ve etiketleyici söz ve tavırlara maruz kaldıklarını ifade etmişlerdir. En basit haliyle bir katılımcımızın rahatsızlığ sosyal çevresi tarafından nazar olarak değerlendirilmiştir: "Nazar dediler... Pek çok hocaya götürdüler bu sebeple. Okuttular beni nazar geçsin diye” (K7). Aynı kişi, ailesinin onu okuttuğu hoca tarafından "cinlenmiş” yorumuyla karşılaştığını söylemiştir: “... Ama bir kadına götürdüler o kadın cin bulaşmış dedi. Ona çok sinirliyim mesela" (K7). Aynı katılımcı, çevresindeki insanların dini inancındaki bir eksiklikten dolayı hastalı̆̆ının ortaya çıktığını ifade ettiklerini belirtmiştir: “... sonra bir arkadaşımla konuştum, tamamen tevekkül eksikliği demişti. Teslimiyet eksikliği ve gelecek kaygısl olarak değerlendirmişti. Güvendiğim bir arkadaşım ve o bunu dedikten sonra biraz düşündüm, manevi olarak eksiklik değil ama tevekkülümü artırsam bana iyi geleceğine karar verdim” (K7). Görüldüğü üzere, birey, kendisinde tevekkül eksikliğinin var olduğuna ikna olmuş, dini ve manevi anlamda rahatsızlığ 1 sebebiyle yaşadığı toplumsal damgalanma, şekil değiştirerek içselleştirilmiş damgalamaya dönüşmüştür. Aynı zamanda ilaç tedavisi de alan katılımcı, ilacın tek başına yeterli olmadığını düşünerek geleceğe kaygılanmanın teslimiyet duygularındaki azalmadan ortaya çıktığını düşünmeye başladığını da belirtmiştir.

Hâlihazırda rahatsızlığını kabullenmekte güçlük çeken bir başka katılımcıya sosyal çevresi tarafindan “Allah'ın ona hak etmediği bir hastalığı verdiği” şeklinde bir söylem ile hastalığa karşı bir önyargı oluşturulmuştur: "Dediler $k i, \ldots$ sen çok iyi bir insansin neden senin başına geliyor bunlar diye söylüyorlardı" (K14). Sosyal çevresi tarafından bu şekilde hak etmediği bir şeye maruz bırakı1dığını düşünen katılımcı, rahatsızlığını kendine yakıştıramayarak öz saygısını azaltmış, sosyal çevresinin ona konduramaması ile bu aşırı ve yıkıcı özeleştiriye kendisini mahkûm etmiştir.

Kişiler bu süreçte Müslüman olmaları sebebiyle bilinçli ve güçlü, dolayısıyla sağlıklı olması gerektiğini düşünen bazı doktorlarla da karşılaşmışlardır. Bazıları, dini inancı olmayan ya da kendini dindar olarak görmeyen psikiyatrlar tarafından damgalanma yaşamış, bu sebeple de kendilerini damgalamıştır: “... Doktor da sen bilinçli bir insansin senin burada ne işin var dedi. Ona dedim ki, ben bilinçli olduğumu biliyorum zaten, bilinçsiz olduğum için değil sıkıntılar yaşadı̆̆ım için buraya geldim dedim. Her bilinçli olan çok iyi olamaz. Dalga geçer bir bakış seziyordum... Ama o alaycı bakışı görünce Daha güçlü olmam gerekirdi ben neden buradayım gibi şeyler hissettim. Niye böyle bu rezil duruma geleyim ki bunlar bana böyle yapsin dedim kendi kendime" (K14). Hastalara 
yaklaşımlarından dolayı hastanın oraya neden geldiğini yeniden sorgulatan bazı doktorlar, kişileri muhtemeldir ki başörtülü ya da dini hassasiyetleri olan biri olarak gördüklerinden bilinçli olduklarını, dini/manevi duygularının baskın olduğunu düşünmektedirler. Bundan dolayı psikiyatra gelmelerine gerek olmadan sıkıntısını çözeceğini düşünerek, inançlı insanın psikolojik rahatsızlık yaşamayacağını dile getirmiş, kendilerine gelen hastalara damgalayıcı gözle bakmışlardır. "Terapiye gittiğimde sanki herkes deli ve sen de deli olmak zorundasın gibi bir hisse kapıllyordum. Acaba benim hakkımda ne düşünüyorlar falan diyorum. Çünkü zaylf noktalarımla oradayım. Her zaman kendimi orada yenilmiş ve yıkık hissediyorum... Doktorum başı açık biri. Düşünce yapısı farklı. Çoğu zaman şöyle hissediyorum; ben inançl olduğumu iddia ediyorum bunu uyguluyorum ve ben ezik bir vaziyette onun karşısındayım. Inançl insanın daha sağlam ve güçlü olmasıyla ilgili bir fikrim var" (K13). Hekimlerin kişilere bakışları, kişilerin de kendilerini damgalamalarına sebep olmaktadır. Bu da göstermektedir ki hastalara olduğu kadar sağlık personellerine de hastalıklar ve damgalama konusunda destekleyici eğitimler verilmesi gerekmektedir. Yapılan birçok çalışmada da belirtildiği gibi bazı sağlık çalışanları psikolojik hastalıkları toplumsal yargılarını bir kenara bırakarak değerlendirememektedir (Kuş-Saillard, 2010).

Katılımcılar arasında bulunan ilahiyat eğitimi almış kişilerin din eğitmeni kimliği ile toplumda yer almaları, onların kişisel dini yaşamının yanında mesleki olarak da bir dini misyon yüklenmelerine sebep olmaktadır. Bu durum, onları rahatsızlıklarını inançları ile birleştirerek sorgulama ve irdeleme noktasına daha hızlı taşımıştır. Özellikle dini uygulamaların bilgisine ve mefhumuna sahip yetkin bir kişi olarak görüldüğünden dolayı bir katılımcının rahatsızlık yaşaması, doğrudan dini anlamda yetersiz ve olgunlaşmamış biri olarak damgalanmasına yol açmıştır: "...akrabalarımdan gizleme sebebim bu. Illahiyatçıyım ve başka bir bölümde olsaydım bu durumlarımı daha çabuk dile getirebilirdim belki. Illahiyatçısın ve bu işin içindesin ama sen bile iyi değilsin gibi...” (K13). Aynı şekilde başka bir katılımcı din eğitimcisi olmasından dolayı olsa gerek: "Babam bu durumumu inançslzlık olarak görmüştü, yani ibadet eksikliği ya da tevekkülsüzlük gibi görmüştü. Annem daha çok destek olmuştu bana” (K9) demiştir.

Dindar bir ailede yaşamakta olan bir diğer katılımcı, hastalı̆̆ını dile getirdiğinde ailesinin ona inanmadığını, kendisini ciddiye almayarak yanında olmadıklarını ve durumunu yalnızca iman zayıflığı ve inanç eksikliği ile ilişkilendirdiklerini dile getirmektedir: “...imanın azalmış kendini düşürmüşsün dediler... bu tür bir şeye insan yakalanmaz dediler... şimdi dediler yani, demesem yalan 
olur. Ama ben pek kulak asmadım... Ben her zamanki yaptı̆̆ımı yaptım, ibadetimde de kitabımda da. Hiç değişiklik yoktu” (K15). Bununla birlikte inançtaki zayıflamayı rahatsızlığın direkt sebebi olarak görmemelerine rağmen, iyileşebilmesi için inanç temelli telkinlerde bulunanların sayısı da oldukça fazladır: "Allah'a sığın gibi şeyler diyorlardı ama o kadar. Ben imanımın zayıfladiğını düşünmüyorum sadece hassas ve o kadar da güçlü değilmişim dedim” (K1).

2 katılımcı ibadet ve duaları artırmaları yönündeki teşviklerin yanında, içinde bulundukları durumun Allah'ın verdiği nimetlere karş1 nankörlük, şükürsüzlük olarak algılandığını ifade etmiştir. Bu kişiler; gelir düzeyi iyi, hayatlarında kendilerini sıkıntıya sevk edecek herhangi bir etkenin olmadığını, yani somut bir problem sebebiyle destek almadıklarını belirten kişilerdir. Çevrelerindeki insanlar, ortada somut bir neden göremeyince ya kişilerin rahatsız olduklarına inanmamaktadırlar ya da onların durumunu içinde bulundukları nimete nankörlük olarak görerek onları etiketlemektedir: "Annemin genelde tavrı bunun nankörlük olduğunu söylüyordu. Bu kadar rahat bir hayatta böyle olmak Allah'a karşı nankörlüktür. Senin tevekkülün yok mu diyordu sık sık. Mükemmel olmamız bekleniyor ama biz Gazali değiliz. Her şey çok iyi ama sen problem çıkarıyorsun tavrında oluyorlardı" (K13).

\section{Psikolojik Destek Almış ya da Almakta Olan Dindar Danışanların, Dini/Manevi Açıdan Yaşadıkları İçselleştirilmiş Damgalamaya Dair Görüşleri}

Katılımcılara rahatsızlıklarını dini bir yükleme yaparak tanımlayıp tanımlamadıkları sorulduğunda ve destek alma süreçlerini inançları ile ilişkilendirip ilişkilendirmedikleri sorusu yöneltildiğinde, katılımcıların kendi kendilerini damgalayıcı bir bakış açısına sahip oldukları görülmektedir. Bazılarının toplumsal damgalamadan etkilenerek bazılarının ise doğrudan rahatsızlı̆ğ öğrendikleri ilk andan itibaren kendilerini "imanı zayıflamış, tevekkülsüz" veya bir günahları sebebiyle "cezalandırılmış" hissederek damgaladıkları verdikleri yanıtlar yoluyla anlaşılmaktadır.

Katılımcıların hastalıkları değerlendirmede inanç temelli olumsuz bir yaklaşım içerisinde olmaları veya dini inanç ve ibadet yaşamları ile aralarına bir mesafe koymaları, olumsuz dini başa çıkma olarak da değerlendirilebilmektedir. Damgalanma ile olumsuz dini başa çıkma birbirine girift konular olmakla birlikte, bu iki olgu bir sebep-sonuç ilişkisi olarak da değerlendirilebilir. Nitekim olumsuz dini başa çıkma, bireyin içinde bulunduğu durumu kaldırabilmek 
için kullandığı bir yöntem olarak, yardım alma sürecinin getirdiği bir sonuçtur. Damgalama ise, bireyin yardım alma sürecini anlamlandırırken bir yargıda bulunması ve en önemlisi de bu yargılamadan memnun olmamasıdır. Damgalanma hissi nedensellik, dini başa çıkma ise tepkisellik açısından değerlendirilmelidir. Kişi kendi kendini damgalayarak olumsuz dini başa çikma yaşayabileceği gibi, olumsuz dini başa çıkma yaşadığında damgalanma hissi de ortaya çıkabilmektedir. Bu nedenle inanç temelli damgalama, kendisini literatürde olumsuz dini başa çıkma içerisinde göstermektedir. Ancak bu iki konunun sınırlarının netleştirilmesi önemli ve gereklidir.

Katılımcıların 5'inin ifadelerinden, daha önceden işledikleri bir günah sebebiyle cezalandırıldıklarını (K19, K18, K9, K13, K4) düşündükleri anlaşılmaktadır. Bu süreci yaptıkları suç ve hatalar sebebiyle bir karşılık olarak gördüklerini belirtmiş̧tir. 2 katılımcı tesettürüne dikkat etmediği için, "Önceleri başım açıktı sonradan "bu şekilde giyinmemin bir cezast" olarak düşünüyordum. İlk başta "büyük bir günah işlediğim için bunun bedelini mi ödüyorum acaba" hissi olmuştu, ya da "daha büyük bir şey gelecek başıma ve bu onun hazırlı̆̆l" gibi düşündüm. Büyük bir darbe alacağımı düşünüyordum" (K9); ibadetlerindeki özensizlik için: "Biraz da günahlarımın cezası olarak görüyordum. Allah'ın yolunda gitmediğim içindir galiba diyordum. Inançlı biriyim ama başım açık, namaz yok. Bunlardan sebep bir şeyler ruhumu siklyor diyordum" (K19); şükürsüzlüğü ve günahları için: “...mutlu olmam gereken bir yerde bile mutlu değilim, her şeyim var, her şey yolunda ama ben niye mutlu değilim. Çoğu zaman günahlarımdan dolayı cezalandırllyor muyum hissine kapılyyorum" (K13); bir diğeri eski eşinin nişanlılık döneminde elini tuttuğunu belirterek, dini açıdan uygun olmayan bir davranışta bulunduğu için cezalandırıldığını düşünmüştür: "Eşim Allah bizi cezalandırdı diyordu. Bu benim çok psikolojimi bozuyordu. Biz yanlış olan bir iş yaptık ve Allah da bize bunu verdi diyordu. Bunlarda hep suçlu hissettim ve hep Allah 'tan ceza almış hissediyordum. Herhalde çizgiyi aştım Allah da bunu bana imtihan olarak verdi dedim. Tek verebildiğim cevap ..." (K4).

3 katılımcı, Allah'ın onları terbiye etmek için hastalık verdiğini (K18, K14, K4) düşünmektedir: "Bir de diyordum ki, ben kendime değer veriyordum, kendime saygı duyuyordum... Kendim için ve her şey için kurallar olması gerektiğin inaniyordum, en iyi olmam gerektiğine inanlyordum. Belki de bu benlik, sevgimi törpülemek amaçlı bana böyle bir şey verdi diyordum” (K14). “...Ya aslinda bunun gerçek sebebi neydi biliyor musunuz, ben "Allah'a karşı geldim. Allah da dedi ki kendine gel!" Allah diyor ki, bir kalpte iki sevgiyi barındırmam. Ben 
eşimi o kadar çok sevdim ki Allah'ı unuttum" (K4). Yıllar geçmiş olmasına rağmen tedavilerinin bitmemesini de yine terbiye edilmelerinin devam etmesi olarak değerlendirmişlerdir: "Allah biraz hayatı tanıtmak istedi bana gibi geliyor. Asll terbiye etti. Tam tersine duruldum. Ben kendi içime döndüm. Ama almam gerekeni daha tam almadım, daha terbiye olmam gerekiyor o sebepten rahatsızlı̆̆ımın devam ettiğini düşünüyorum. Ben bu olaya tamamen böyle baklyorum" (K18). Katılımcılardan biri rahatsızlığını kendine açıklamaya çalışırken, Allah'ın onu dünyada başıboş bıraktığını, Allah'ın kendisini sevmediğini düşündüğünü ve bu sebeple hastalık yaşadığını ifade etmiştir: "Sanırım Allah beni sevmiyor" diyordum. Başıboş bırakılmış ve yalnız hissediyordum. Namaz kılmadığımda "namaz kilmayım ve çarpıllyım ki Allah tarafindan umursandığlmı hissedeyim" demiştim" (K17).

Bir katılımc1, Allah'ın kendisini hatırlatmak istemesi nedeniyle ona hastalık vermiş olabileceğini belirterek, "İlaç tedavi tabi ki bunlar gerekli şeyler ama dermanın gerçek sahibini öğreniyorsunuz. Sana kendini hatırlatıyor. Sen inkâr ediyorsun hattrlamak istemiyorsun. Sonra biraz daha seni sarstyor, sen yine hatırlamiyorsun, sonra biraz daha. Sonra zelzele şeklinde hatırlatmak istiyor" (K18) hastalığı süresince devam etmekte olan krizlerin de nedeninin bu hatırlatma isteği olduğunu belirtmiştir.

Katılımcılardan 3'ü hastalıklarını ilk öğrendiklerinde, inançlarındaki bir bozukluğun yahut ibadetlerindeki zayıflamanın bu hastalığa sebep olup olmadığını sorguladıklarını söylemiştir. Kendilerine böyle bir teşhis koydukları için de tedavi yöntemini de bu şekilde belirlemişlerdir: " $O$ an onu da sorguladım yani acaba imani noktada bir sıkınım mı var, ibadetlerimde samimiyetim zarar gördü de bir şeylerde yanlış yapıyor muyum da ben böyle hissediyorum diye düşündüm. Bu sebepten ibadetlerimde de daha dikkatli olmaya başlamıştım. İmanımı tazelemeye çalışmıştım” (K3); “... evet imanımda bir problem var tevekkülüm yok Allah'a güvenmiyorum gibi düşüncelere kapllyordum” (K17). 2 kişi de rahatsızlığın yaşanma sebebini, "iyi insan olmaya çalışmaktaki kırılmalar" olarak düşünmüş: “... Ama ben okumayı seven, yaşamayı seven insanlara örnek olmaya çalışan kendini bilen biriyim. Ben böyle bir sıkıntıya düşecek biri değilim diyordum. Peygamber onca şey yaşamış ve sinir krizleri geçirmemişken dili tutulmamışken ben neden böyleyim diyordum. Evet, burada iman eksikliği de olabilir" (K14) diyerek kendini ifade etmiştir. Katılımcılardan bir kişi, psikoloji eğitimi almış olan, psikolojik yardım almasından dolayı damgalanma kaygısı duymayan ve hastalığ 1 ile barışık olduğunu belirtmiştir. Bu süreçte inancında 
bir eksiklik hissettiğini de söyleyen katılımc1, bu hissettiği eksikliğin inanca dayalı olmadığını, bir tür entelektüel arayış olduğunu yoğun bir vurguyla dile getirmiştir. Bu ikilem görüşme esnasında araştırmacı için dikkat çekici olmuştur.

Bir katılımcı, psikolojik rahatsızlıkları da fiziksel rahatsızlık gibi gördüğünü ancak iki tür hastalığın da maneviyat eksikliği ya da inanç zayıflığından kaynaklandığını düşünmektedir. İmanın eksildiği dönemlerde gerek fiziksel gerekse psikolojik rahatsızlıkların tevarüs ettiğini ifade eden bu katılımcıya göre, bireyler hayatlarında günahsız ve hatasız olmayı başardıklarında herhangi bir sıkıntıyla karşılaşmayacaklardır: "Düşünce çok ayrı bir şey ama depresyon fiziksel olarak da çok etkiliyor... Hormonlar için mesela, ilaç tedavisi gerekiyor. Ama şu var ki, manevi olarak geriye gittiğim, bir şeyleri azalttığım zaman bu bende fiziksel bir rahatsızlık olarak da ortaya çıkıyor" (K4).

Literatürde yapılmış diğer çalışmalar incelendiğinde görülmektedir ki, eski çağlardan günümüze kadar hastalıkların nedenleri tartış1ırken dini inanca başvurulmuş, tedavi yöntemleri manevi uygulamalar ve dua gibi yollar olmuştur. Elbette ilahi dinlerin nihai amacı, hastalıkların nedenleri konusunda aydınlatma yapmak veya insanların nasıl tedavi edileceğine dair öneriler sunmak değildir. Fakat günümüze kadarki süreçte din ve sağlı ilişkisine bakıldığında asıl öne çıkan, sevgi ve adalet üzere Allah tasavvuru olan inançlı insanların sağlıklı din algılarıyla hem maddi hem de manevi iyi oluş içinde oldukları; inanç, ibadet ve ahlaki bozulmalar sonrasında ise cezalandıran bir Allah tasavvuru sebebiyle Allah'ın insanlara gerek imtihan gerekse ceza olarak hastalıkları verdiği olgusudur (Atmaca, 2010). Hastalıkların, günahların karşılı̆̆ında bir kefaret, ceza olarak verildiği veya bir yasağı çiğnemeleri nedeniyle Allah'ın kendilerini ıslah etmek için hastalık verdiği görüşü dindar insanlarda oldukça yaygındır. Nitekim Apaydın, Özer ve Aydın'ın (2008) hastalık sürecinde bireylerin dini manevi duyguları ile ibadet ilişkileri arasındaki etkileşimi ele aldıkları çalışmada, bireylerin hastalıklarla ilk karşılaştıklarında önce tıbbi tedavi yerine inanç ve ibadete yöneldikleri, hastalıktan kurtulabilmek amacıyla dua ve ibadetlerini artırdıkları ve sıkça tövbe ettikleri, yardım alma sürecinde Allah'a isyan etmeyerek ibadetlerini ve şükürlerini artırdıkları tespit edilmiştir.

\section{Katılımcıların Psikolojik Yardım Alma ile Dini İnanç İlişkisine Dair Görüşleri}

Kişilerin rahatsızlık yaşamadan önce sosyal damgalamaları ne kadar çoksa, içselleştirilmiş damgalamalarının gücü de o oranda fazla olmaktadır. Bu nedenle, 
dindar bireylerdeki psikolojik yardım alma durumunun nasıl değerlendirildiğini anlayabilmek amacıyla katılımcılara "Sizce Müslüman depresyona girer mi?" sorusu yöneltilmiştir. Bu soruya verilecek yanıtların, hastaların içinde bulundukları yardım alma sürecini değerlendirirken etkisinde kalabilecekleri muhtemel yargıları keşfetmede ve katılımcıların yardım alma süreci ile dini inanç arasında kurdukları ilişkiyi anlamada faydalı olacağı düşünülmüştür.

Müslümanların da psikolojik rahatsızlığa yakalanabileceğini düşünenlerden 2 kişi bu durumu, Hz. Peygamberin de çeşitli nedenlerle depresyona girdiğini referans göstererek açıklamaktadır: “... Kendim Nas Felak okudum. Çünkü peygamber de öyle yapmış. Ama çok fazla kapıldım o düşünceye, cinlendim mi hissine (güler) Herhalde ben iyi olamayacağım dedim. Buna da çok kapıldım" (K15). Bir diğer katılımc1, "Inançlı insan hasta olmaz lafindan nefret ediyorum çok tepkiliyim. Çünkü öyle bir şey yok. Peygamberin de içinin sılkılıp intiharl düşündügüune dair bazı rivayetler var. Yani herkes bunu yaşayabilir bunun inançla ilgisi yok" (K5) şeklinde yanıt vermiştir.

Müslümanların psikolojik rahatsızlıklar yaşayabileceğini düşünen diğer 4 katılımcı, bu iddialarını kişinin beşer olması ile temellendirerek, insanın noksan bir varlık olduğuna vurgu yapmışlardır. İnsanın fiziksel hastalıklarda olduğu gibi psikolojik olarak da hasar görebileceğini dile getirmişlerdir: "Hepimiz insanız şaşar beşeriz, hayat öyle bir şey ki ne olacağı belli olmuyor, seni en üst noktadan en alt noktaya getirebiliyor. Müslüman da insan o demir değil... Kendisinin dinle ilgisi olmadiğg hale sürekli inançla ilgili telkinlerde bulunuyorlar... Bence en büyük eksiklik insanı tanımamak" (K3).

Müslüman sizce depresyona girer mi sorusuna yanıt olarak 3 katılımcı inancın, psikolojik rahatsızlığa sebep olmadığını, aksine başa çıkabilmek için yardımcı güç olduğunu dile getirmişlerdir: "Evet, inancınızı artırmanız hastalığa iyi geliyor ama sebebi bu değildir. Din hayatımızda var ve onun var olduğunu bilmek bizi rahatlatıyor" (K7). Bir başka katılımcı ise farklı bir çıkarımda bulunarak rahatsızlığın yaşanma sebebini "iyi insan olmaya çalışmaktaki kırılmalar" olarak düşünmesi, yaşanan tedavi sürecinin olumlu yönelimlere teşvik edici bir sürece de götürebileceğini göstermiştir. “... Ama ben okumayl seven, yaşamayl seven insanlara örnek olmaya çalışan kendini bilen biriyim. Ben böyle bir sıkıntıya düşecek biri değilim diyordum. Peygamber onca şey yaşamış ve sinir krizleri geçirmemişken dili tutulmamışken ben neden böyleyim diyordum. Evet, burada iman eksikliğine giriyor olay, belki o da olabilir" (K14). Bu bulgu, yardım alma sürecindeki kişilerin olumlu dini başa çıkma kullandıklarında 
Allah'1 yanında hissettiklerini ve bu tasavvurda onun suçlamasını ve ötelemesini değil, yaşamlarına destek veren iyileştirici ve affedici özelliklerini öne çıkarttıklarını göstermektedir.

Psikolojik yardım almanın inanç eksikliğinden değil, aksine inanç fazlalığından kaynaklanabileceğini söyleyen 2 katılımcı ise ilginç tespitlerde bulunmuştur. Bireylerin hayatlarını devam ettirirken fazlaca ahlaklı ve dindar olmaya çalıştıklarında, sahip oldukları inancın strese neden olabileceği ve onlara zarar verebileceğini düşünmektedirler: "Bazen tam tersini düşünüyorum, inanan insanın daha çok problemi olur bence, inanmayan insanın problemi olmaz. İnanan kişi kendisinin sınırlı ve aciz olduğunu sonlu olduğunu biliyor. Kendimi aciz hissediyorum. Bu yüzden inanç hem olumlu hem olumsuz etki edebilir" (K9), “...ben bu düşünceye hiç katılmiyorum, Müslüman güzel ahlakl olmak uğruna daha çok depresyona bile girebilir bence" (K6). Bir katılımc1 ise, "Psikolojik rahatsılılkları çok imanla ilişkilendiremiyorum. İnançsız olsam daha isyankâr olurdum belki ama inançlı olduğum için de daha çabuk iyileşmedim. Bana psikolog iyi geldi" (K16) diyerek inancın psikolojik rahatsızlı̆ga olumlu veya olumsuz bir etkisinin olmadığını ifade etmiştir.

\section{Psikolojik Destek Almış ya da Almakta Olan Dindar Danışanların, Bu Süreçlerinde Manevi Desteklenme İhtiyaçlarına Dair Görüşleri}

Araştırmaya katılanların tamamı kendini dindar olarak tanımlayan, psikolojik tanı alarak tedavi süreci geçirmiş veya geçirmekte olan kişilerdir. Farklı psikologlardan çeşitli terapiler alan katılımcıların din temelli damgalanma korkusu ya da deneyimi yaşandıklarında, dini ve manevi açıdan desteklenmeye istek ve ihtiyaçlarının olup olmadığı, bu ihtiyacın karşılanıp karşılanmadığı ve bununla ilgili ne düşündükleri ele alınmaya çalışılmıştır. Burada katılımcılardan bir kıs$\mathrm{m}$, dini/manevi damgalanma konusundaki uzman desteğinin yanında, bir manevi danışmanın nasıl yaklaşması konusunda da bazı önerilerde bulunmuşlardır. Bu bulgulara da araştırma çıktıları kapsamında bu başlık altında yer verilecektir.

Kat1lımcıların 5'inin (K5, K6, K7, K11, K17) önyarg1 ve damgalamanın önlenmesi konusunda dindar hasta ve hasta yakınları için uzmanlarca bilgilendirmenin gerekliliğini öne sürerek manevi danışmanlık ve rehberliğe ihtiyaç duyduklarını ifade ettikleri görülmüştür. Bu bağlamda katılımcılardan biri, "Bazı insanlar hastalıklar konusunda çok sabit fikirli olduğu için bazıları da bilmediği için farklı yaklaşabiliyor duruma. Destek ihtiyacı olabilir." (K6) diyerek manevi danışmanlık yardımıyla hasta ve çevresindeki diğer insanlar için hasta- 
lığın tanımlanmasının değişmesi bakımından desteğe ihtiyaç duyulduğunu belirtmiştir. Bu tanım ve yorum değişikliği damgalanmayı önleyecek, kişilerin rahatsızlıklarını bir başkası ile paylaşabilmesini sağlayacak, böylece rahatsızlığın teşhis ve tedavi süresini hızlandıracaktır. Rahatlıkla yardım alma merkezlerine başvuru yapabilen hastanın, rahatsızlığı ilerlemeden tedavisi gerçekleştirilecektir: "Hastalıkların anlaşılması ve kabullenilmesi sürecinde ailelerin ve kişinin desteğe ihtiyacı oluyor. Çünkü durumu anlamlandırmakta güçlük duyuyoruz. Kaldırılabilir bir acı olmasın sağlamak gerekiyor” (K7).

2 katılımcı, manevi danışmanlığın hastalıkların yorumlanması ve kişilerin tedavilerinde doğru yönlendirilmesi konusunda bir ihtiyaç olduğunu ifade etmiş, bu yönlendirmelerin sağlıkl yapılabilmesi için uzmanlarca yapılması gerektiğini belirtmiştir: "Insan kendini daha iyi tanımak, sorunlarının nereden kaynaklandığını görmek sorunu tespit etmek ve çözmek ister. İnsanları psikoloğa götürmek için de ön bir çaba gerekiyor. Bu konularda uzmanlarca bilinçlendirmenin ve farkındalık kazandırmanın gerekli olduğunu düşünüyorum." (K20); "Hastalıkların anlaşılması ve kabullenilmesi sürecinde ailelerin ve kişinin desteğe ihtiyacı oluyor. Çünkü durumu anlamlandırmakta güçlük duyuyoruz. Kaldırılabilir bir acı olmasını sağlamak gerekiyor...” (K7).

Hastaların bazı durumlarında ihtiyacının manevi destek olduğu da bu çalışma içerisinde görülen bulgulardan birisidir. Bu ihtiyaçlarını karşılayacakları doğrudan bir adres olmamasından ya da probleminin çözümünde manevi kısmın eksik kalmasından dolayı iyileşememe düşüncelerinden de bahsetmişlerdir. Bir katılımcı görüşme sırasında manevi danışmanlık diye bir kurumun olduğunu öğrenmiş, ihtiyaç duyduğu psikoloji ve dini manevi desteği bir arada bulabileceğini anladıktan sonra araştırmacıdan manevi danışmanlık tavsiyesi istemiştir: "Iyi olurdu bence. Psikologlarda çok imani konular konuşulmuyor. Şu an ihtiyaç duymuyorum ama bunu düşünürsem, ihtiyacım olursa nereye gideceğim? Tavsiye edeceğiniz yer var mı?" (K10); "Hiç manevi desteğe yönelten olmadl, başvurmayı düşünürüm. ... benim gittiğim bir psikolog beni yogaya yöneltmişti. Ama bir hocaya gitsem düzelir miyim düşüncesi hala var" (K9).

Bir katılımcı da dini algılayış ve yaşayıştaki yanlışlıkların onarılması nedeniyle manevi danışman ihtiyacı olduğunu bildirmiştir: “...kimi insanlar dini sadece ritüellerden ibaret görüyor. Dinin güç veren yanını göremeyebiliyorlar ... Din güç veriyor diye düşündüğünde de bu kez sosyalden kendini tamamen çekme oluyor iliş̧kisini kesiyor... Çok boyutlu bakmak gerektiğine inaniyorum. İnsanın o dinin içindeki tüm doğru parçaları tek başına eşleştirme gücü her zaman olamiyor" (K20). 
Diğer katılımcılardan 7'si, psikoloğun kişinin inancıyla ilgili kaygıları ile ilgilenmemesi ve onları önemsememesi nedeniyle manevi danışmanlığa ihtiyaç duyduğunu ifade etmiştir (K18, K19, K8, K12, K9, K10, K13). Örneğin; "Bundan önceki gittiğim psikolojik danışman beni inancımla ilgili konularda anlamıyordu. Ben suçluluk duyup tereddüt ettiğim inancımla ilgili konularda aman boş ver diyordu, o tavsiyeyi bana komşu da verirdi. Inancımla ters düşecek konulardaki suçluluğumu anlayamıyordu" (K12); "Ben bunu zaman zaman hissediyorum. Doktorum bana desin ki bu bir imtihan. Böyle bir şeyi duymak istiyorum. Ciddi anlamda psikoloji bilen inançl insanlara ihtiyacım var. Inancı bir kenara koyup onsuz yol alınmıyor zaten. Bir zemin bir anlamı olsun” (K13).

Kat1lımcilardan 9'u (K18, K14, K8, K4, K5, K16, K3, K12, K17) terapinin inançla bir arada gitmesi gerektiğini düşünmesi nedeniyle manevi danışmanl1ğa ihtiyaç duyduklarını ifade etmişlerdir: "Ben düşünüyorum evet. Çünkü o an hasta olan kişi dini duygularının farkında olmuyor. Inancın olumlu bir etkisi var o döneme, ama bunu hissedemediğiniz için katkısı da olmuyor. Ama birinin o anlamda destek olması gerekiyor çünkü hep bir tarafi boşluk oluyor insanın. Evet, başvurmayı düşünürüm. Insanları da yönlendiririm” (K14) diyerek manevi danışmanlığın kişinin dini duygularını harekete geçirerek tedavisini hızlandıracağını düşünmektedir. Bir diğer katılımcı da terapi sürecinin inancıyla bir arada gittiğini söyleyerek psikoloğun manevi duygularını da etkilediğini dile getirmektedir: "Mesela ben psikoloğuma namazlarımla ilgili sorun yaşlyorum dediğimde bana sohbet göndermişti. Bunu başka bir psikolog anlayamazdı. Bir arada gidiyor inançla... Maneviyatımı da etkiliyor psikolog” (K8).

Din ve psikoloji farklı zeminlerde değerlendirilse de bunların aynı yeri eğitmeye ve iyileştirmeye çalıştığını düşünen bir katılımcımıza göre, manevi danışmanlık hastalığın çözümlenmesini de kolaylaştıracaktır: "Bugün din ve psikolojiyi ayrı ayrı tartışmak değil de birlikte aynı yerde konuşabilmek lazım, bu yüzden kişiye manevi destek verilmeli ve inancı ile aldĭ̆ desteği birleştirmeli. Bu hastalığın çözümünü kolaylaştıracaktır” (K12).

Üç katılımcı yardım alma sürecinde onlara yol arkadaşlığı edecek birine ihtiyaç duymaları nedeniyle (K18, K19, K20) manevi desteğe ihtiyaç olduğunu ifade etmişlerdir: "Manevi destek uzmanı olsa ben başvururum. Hastaların çoğu hastalıkla uğraşırken çevreleri ile ilişkilerinde ve hastalığı yaşama süreçlerinde, o hastalıkla yaşayabilmeyi öğrenme sürecinde çok büyük sıkıntılar yaşlyorlar. Bu açıdan manevi anlamda destek iyi olurdu." (K5) diyen katılımc1, tedavi gerçekleşene değin hastalığa uyum sağlama konusunda da manevi danışmanların yardımcı olabileceğini ifade etmiştir. Bir diğeri, "Ben manevi danışmanlığa 
başvurmayı düşünürüm ve ona sadece panik atakla ilgili gitmem, birçok şeyle giderim. İçimi dökmek derdimi de söylemek isterim, bir tartışmada haklı mıyım haksı mı bunu duymak isterim, yönlendirilmeyi isterim." (K18) sözleriyle hastalıkla baş etme yöntemlerinin dini ve manevi anlamda da desteklenmesi gerektiğini ifade etmiştir. Çok fazla arkadaş edinemeyen, hastalı̆̆ı nedeniyle de birçok arkadaşı ile artık görüşmeyen bir katılımcı konuşabileceği biri olması açısından manevi danışmana ihtiyaç duyduğunu söylemiştir: "Tabi ki manevi danı̧̧mana da başvururum. Bunun çözümünü her yerde aramaya çalışıyorum. Zaten hastalıktan sonra daha çekingen daha içe dönük oldum. Konuşabileceğim herkese giderim. " (K19). Bir katılımcı ise dini kaygıları olan danışmanlara her konuda daha çok güveneceğini söyleyerek manevi danışmana ihtiyaç duyduğunu dile getirmiştir: “...öyle bir danışmana ihtiyaç duyarım, isterdim. Ben helal haram kavramlarını bilen insanlara ihtiyaç duyuyorum en azından insanlara yaklaşırken de bu şekilde yaklaşırlar. Dinin girdiği yerde hiçbir bozukluk olmuyor, ama gerçekten dini bütün insanlarsa. Ne seni kandırırlar ne saygısızlık görürsün. Dini kaygılarını da paylaşır konuşursun ” (K18). Buradan da anlaşılmaktadır ki manevi danışmanlar, dinin temsilcileri olarak algılanmaktadırlar.

\section{Katılımcıların Manevi Danışmanlık Hizmetlerinden Beklentileri}

Araştırmada katılımcılara, manevi danışmanlık ve rehberlik hizmetinin nasıl olması gerektiği, bir manevi danışmanın nasıl davranmasını bekledikleri sorulmuş, onların bu konuda önemli gördükleri noktalar tespit edilmeye çalış1lmıştır. Sorular doğrudan hastalığı ya da rahatsızlığı olan kişilere yöneltildiğinden, katılımcılar manevi danışmanlardan beklentilerini öneri olarak sunmuşlar bunlar da yedi başlıkta toplanmıştır.

Danışmanın damgalayıcı/önyargılı olmaması. Özellikle hastalığından ötürü damgalanma korkusu yaşadıklarından dolayı psikolojik yardım aramaktan çekinen, sosyal çevrelerinin yanında psikolog ve psikiyatrlar ile sağlık personellerinin de kendilerine damgalayıcı yaklaştıklarını dile getiren katılımcıların manevi danışmanlara önerileri, hastalara toplumun yüklediği belli kalıp yargılarla bakılarak damgalayıcı yaklaşılmaması konusundadır: "Psikolog çözüm değil diye bakıyorlar. Olayı karışık hale getirdiğini düşünüyorlar. Psikolog kendisini çok iyi yetiştirmemişse o da sizi bir kalıba sokmaya çalışıyor. Belli bir eğitimden çıklyor ve size o gözle baklyor. Kişiler de bundan korkuyor olabilir. Bunu haklı görüyorum” (K2). Nitekim toplum içerisinde dile getirilmekten çekinilen bir konu olan cinsellikle ilgili rahatsızlıklarda da benzer bir 
sorun ile karşılaşılmaktadır. Subaşı'nın (2016) cinsel sorunlara yönelik manevi danışmanlığı konu edindiği çalışmasında, manevi destek uzmanının danışanını önyargısız ve yargılamadan dinlemesi gerektiği vurgulanmıştır. Yargılandığııı ve eleştirileceğini hisseden danışanlar, o ortamdan acilen ayrılmak isteyeceklerini ya da orada kaldıkları süre boyunca rahatsız ve kötü hissederek olumsuz etkileneceklerini ifade ederek manevi danışmanın tarafsız bir duruş ile danışanını dinlemesi ve kendisini ifade etmesine izin vermesi gerektiğini belirtmiş̧tir.

Küçümseyici değil, anlayışlı ve değer verici olmaları. Katılımc1ların bazıları (K18, K19, K20) sağlik personellerinin hastaya gereken değeri vermedikleri ve özenle yaklaşmadıklarını düşünmektedir. Elbette bunlar öznel yorumlar olduğu için gerçekte olup olmadığından çok kişilerin bu konudaki his ve algıları üzerinden bu durumun ifade edildiğinin de altını çizmek gerekir. Tüm hastalar değer görmeyi ister. Fakat psikolojik hastalıkların tedavilerinde fiziki hastalıklara göre kişilere daha özverili ve ihtimamla yaklaşılması gerekmektedir. Çünkü psikolojik yardım almada birçok kişi, sağlık servislerine damgalanma korkusu nedeniyle başvuramamaktadır (Özmen ve Taşkın, 2004).

Bir katılımc1, doktorunun onu dinlerken tahammül edemediğini ve onun durumunu anlayışla karşılamadı̆̆ını ifade etmiştir: “...psikiyatra gittiğim zaman bana bir keresinde ses tonumu düşürmemi söylemişti. Ben oraya karnım ă̆rıyor diye gitmedim, psikolojim bozuk... Bu açıdan psikologlara hiç güvenmiyorum anlayışlı değiller. Danışmanlar da daha profesyonelce ve anlayışlı davranmalılar.” (K18). Sağlık çalışanları içerisinde işini özveri ile yapanların yanında, her meslek grubunda olduğu üzere muhatabını yeterince anlayamayanların olması muhtemeldir. Görüşme yapılan katılımcılar arasında psikolojik destek aldığı sağlık personelinden memnun olmayanlar da olmuştur. Öyle ki sağlık personellerinin ilgisizliği ve küçümseyici tavır ve davranışları, kişilerin yara almış psikolojilerini daha kötüye götürecektir (Kuş-Saillard, 2010). Bu nedenle hastaya pozitif yaklaşılmalı, danışman onu anladığını ve onun tedavisi için çaba göstereceğini, en önemlisi de böyle bir rahatsılılı yaşamış olsa dahi değerinden hiçbir şey kaybetmediğini ona hissettirmesi gerekir. Çünkü her insan, çok değerli ve kıymetlidir.

\section{Dinin de içinde olduğu konularda buyurgan, kınayıcı ve manipü-} latif yaklaşmamaları. Maneviyat, bireyin aşkın varlık ile öznel bir bağ kurmasıdır, ona anlam katan, duygu, düşünce ve uygulamalarını şekillendiren değeridir. Din ise insanların üstün güç olarak kabul ettiği bir varlığa az ya da çok bilinçli ve gönüllü bağlılıklarını ifade eder (Horozcu, 2010). Bu kabul görmüş 
inanç sistemi inananlarının yaşamlarının her alanında hatta edindikleri amaçlarda dahi etkili olmaktadır. Bu yönü ile dinlerin yaşama dair belli yasaları ve inanca bağlı belli ritüelleri vardır. Ancak manevi danışmanın danışanına dini kuralları dayatması söz konusu olamaz. Manevi danışmanlık hizmetinin amacı, danışanlara dini öğretmek veya onlara doğru dini anlayışı yerleştirmeye çalışmak değildir.

Katılımcılar, manevi danışmanlık hizmeti veren uzmanların danışanın dini düşüncesine saygı duymalarını, taraflı ve önyargılı yaklaşmadan kişinin isteği dâhilinde dini görüş, yorum ve açıklamada bulunmalarını, aksi halde danışanını herhangi bir dini düşünce veya davranışlar konusunda yönlendirici olmamalarını istemektedirler: "Bu çok zor ama objektif olmaları gerekiyor. Ben ilk psikoloğa gittiğimde örtülü değildim, birkaç yll sonra kapanıp gittim. Psikoloğum da örtülü biri olduğu için beni tebrik etti, çok sevindi falan. Bir gün açılsam tekrar kabul görebilir miyim diye düşündüm mesela orada... Insan çünkü danışmanını bir otorite olarak görüyor. Dinde otorite çok mümkün değil, çok yoruma açı durum var. Danışman otorite olursa yanlış bir yere gidebilir. Kurumsal bir rütbe ile danışman gibi değil de, ögüt veren biri olarak yer alması daha sağllkll olur" (K20).

\section{Danışmanlarn görüşme strasında mimik ve tepkilerinin kont-} rollü olması. Psikolojik bozuklukların tedavisinde sağlık personelinin tüm davranışları bir yana jest ve mimikleri de çok önem arz etmektedir. Bazı katılımcılar danışmanları ile konuşurken onların hiç tepki vermediklerini, bunu danışanını etkilememek için yaptıklarını bildiklerini, ancak bunun danışanda farklı yansıdığını, danışmanın kendisini anlamadığı hissi oluştuğunu ifade etmişlerdir. Burada danışmanın onaylayan veya reddedici tarzda yönlendirici mimikleri hariç, danışanını anlayabildiğini belli eden göz kontağı kurarak danışanını can kulağı ile dinlediğini hissettirmesi gerekmektedir: "Danışmanların mimiksiz ve tepkisiz poker surat olması gerekir derler ama bunu abartmasinlar. Mesela benim terapistim poker surat olduğunda anlattılarımı anlamıyormuş gibi geliyor. Daha dengeli ve tecrübeli olsunlar bu konuda" (K20).

\section{Manevi desteği uygulamalarla birleştirici bir dil ve davranş̧lar}

bütünü ile yaklaşmaları. Rahatsılı 1 ğ sebebiyle birey, yaşamında anlam ve his kaybına uğrar ve bu anlamı yeniden kazanabilmek için varoluşsal sorgulamalara ve arayışlara yönelebilir. Sorgulamalarına yanıt verebilecek, yitirdiği anlamı geri kazandıracak, kısacası onu yaşama bağlayarak iyileştirecek olan temel şeylerden biri de ait hissettiği dine yönelik inançlarıdır (Horozcu, 2010). 
Çalışmaya katılanların tamamı, inançlı insanlardır. Psikoloğun ilk aşamada kendilerine iyileşme konusunda destek olduğunu ancak bağlı bulundukları dine yönelik hislerinin ve inançlarının iyileşme sürecine olumlu etki etmesinden dolayı katılımcılar kaybettikleri bu hislerini danışmanların ortaya çıkarmasını ve inancını göz ardı etmemelerini önermişlerdir. "Terapiden çıkınca namaz kıllyorum mesela, ikisini birleştirip beni etkileyen bir şey ararım. Gündelik yani herkesin bu tarz şeyler yaşayabileceğinden girip, herkesin imtihan yaşadĭ̆gnı ve oraya güzel bağlamaları gerektiğini düşünüyorum." (K13); "Mesela ben namazımı düzenli kilamıyorum, bunu manevi uzman duymalı. Ama ben bunun yanında hiçbir şey de yapamıyorum. Ben sadece namaz değil kitap da okuyamiyorum, kursa da gidemiyorum, temizlik de yapamiyorum. Bunlar bir arada tedavi edilmeli. Bunların tümüne odaklanması lazım uzmanın..." (K5).

Doğrudan kişiye özel ve durumunu gözeterek bir dil kullanmalar. Katılımcıların psikoterapi veya ilaç tedavisi aldıkları süreçte psikologlara ve psikiyatrlara bakışlarında da bazı değişkenler oluşmuştur. Görüşmeye katılanların 2'si psikologların sorulara genel geçer yanıtlar verdiğini ve yanıtların tatmin edici olmadığını ileri sürerek manevi danışmanın kişinin karakterini, yaşamını ve durumunu temel alan bir yaklaşım benimsemelerini beklemektedir (K20, K18, K5, K4, K13): “Ben Allah'ı rahmet sifat ile tanımlyorum ve bana onun üzerinden bir şeyler söylendiğinde benim bam telime daha iyi dokunur. Ama başkasına da kendi inanç şekline göre tedavi verilmeli. Onlara önerim, kişinin durumunu baz alarak ona yaklaşmalı ve önerilerde bulunmalılar. Genel geçer laflarla basmakalıp cümlelerle değil de doğrudan o kişinin inancını hedef alacak ve onun gösterdiği işaretlerle yönlendirilmesi iyi olur" (K5). Katılımcılar genelleyici bir dil kullanımından rahatsı olmaktadır. Kendilerinin, ailelerinin ve sosyal çevrelerinin dindar olması nedeniyle benzer dini argümanlarla sıklikla karşılaşmış ve bu söylemlerden incinmiş olabilmektedir: "Hastanın ihtiyaçları göz önünde bulundurulmalı” (K18). Dini ve manevi açıdan yük alacak değil yük oluşturacak argümanlar duymanın ya da artık ezbere aldıkları için bir farkındalık oluşturmayan dini söylemlerle karşılanmanın fayda getirmediğine vurgu yapmışlardır.

\section{Yalnız hastaya değil ailelere de bu süreçte dini/manevi konularda} rehberlik ve danışmanlık verilmesi. Özellikle evli olan katılımcılar eşleri için ve genel manada tüm katılımcılar birinci derecede aile üyeleri için manevi danışmanlık hizmetine ihtiyaç olduğunu belirtmektedir. Ailelerin hastalıklar konusundaki bilgi eksikliğinden dolayı kişiye damgalayıcı yaklaşabildiklerini dile getirerek damgalanma yaşanmasa bile ilk aşamada hastalığı fark etme ve 
doğru yorumlamak, teşhis ve tedaviyi hızlandırmak için yardım alma sürecinde tüm aile bireylerine danışmanlık yapılmasını önermişlerdir. "Eşleri birlikte tedavi etmeliler. Ailelere de destek vermeliler. Tek başına olmaz çünkü. Ailenin de sakınması gereken şeyleri söylemeliler. Tek başınıza yaşamıyorsunuz” (K4). Bu öneriler yalnızca sosyal damgalamaya dair önlemler olarak algılanabilir, ancak bugünkü önlemler gelecek nesiller için içsel damgalamayı azaltacak önemli bir atılım olacaktır. Çünkü kişi büyüdüğü toplumun değerlerini içselleştirir.

\section{Tartışma, Sonuç ve Öneriler}

Katılımcıların psikolojik yardım alacaklarını öğrendiklerinde hissettikleri duygulardan anlaşılmaktadır ki, din temelli bir yargılanma olsun veya olmasın, psikolojik yardım alma kabullenilmesi zor bir durumdur. Katılımcılarımızın psikolojik destek almaya yönelik tutumlarının temelinde, toplumun ve yardım alan kişinin değersizleştiği ve itibar kaybettiğine dair olumsuz bir bakış açısı vardır. Birçoğu, rahatsızlıklarını her ortamda rahatça paylaşamadıklarını ifade ederken bu yaşadığı süreç nedeniyle herhangi bir utanç ve saklama ihtiyacı duymayan katılımcıların oldukça az olması, toplumdaki sosyal damgalama düzeyinin hayli yüksek olduğunu göstermektedir.

Genel anlamda toplumsal damgalama içerisinde özellikle dindarların psikolojik rahatsızlıkları bireyin imanının zayıflığı ile alakalandırılarak inanç ve maneviyat eksikliği olarak değerlendirilmeleri, rahatsızlığı yaşayanları dini/ manevi anlamda damgalamaktadır. Dini hayatta elde edilen derinlik dindar insan için bir statüdür. Hem kendi iç dünyalarında hem de çevrelerinden onlara yöneltilen din temelli açıklamalarda bu statüyü korumaya çalışırlar. Bu sosyal statüyü kaybetmemek için dindar kesimin psikolojik yardım almada seküler olduğunu düşündüğü bir psikoloğu tercih etmemesi, ediyorsa da bunu dindar olan aile ve sosyal çevresinden saklamaya çalışması da damgalamaya konu olan diğer bir husustur. Bireylerin yardım alma sürecinde yargılanarak sosyal statülerini ve benlik saygılarını kaybetmiş olduklarını düşünmeleri, bu süreci daha da zorlaştıran etkenler arasındadır.

Araştırmaya katılanların önemli bir kısmı bir günah sebebiyle cezalandırıldıklarını veya Allah'ın onları terbiye ettiğini düşünmektedirler. Bireylerin ibadetlerindeki nitelik ve düzey kaybının bir sonucu olarak kendilerini dini/manevi anlamda zayıflamış olarak görmeleri, kendi deyişleriyle "tevekkülsüz, inancı zayıf, günahkâr" olmaları, hastalıklarının diğer bir sebebidir. 
Dini başa çıkma çalışmalarının geneline bakıldığında, olumsuz dini başa çıkma yönelimlerinin suçluluk ve günahkârlık duygularını anlamlandırmada dindar insanlar tarafından sıklıkla kullanıldığı görülür (Ayten, 2010; Ekşi, 2001). Ayrıca içsel bir suçlamanın yanı sıra toplumsal damgalanma konusunda da tedirgin oldukları görülmüştür. İlahiyat mezunu iki katılımcı, hastalıkları nedeniyle ibadetlerinin azaldığını, bu nedenle sürekli aileleri tarafından ibadetleri konusunda uyarıldıklarını, özellikle Din Kültürü ve Ahlak Bilgisi öğretmeni olan biri, namaz kılmamasından dolayı ötekileştirileceğinden endişe duyduğunu belirtmiştir.

Araştırmada özellikle ailenin, içsel ve toplumsal damgalamaya ilişkin olumlu ve olumsuz yönde önemli bir faktör olduğu görülmüştür. Tedavi sürecini ailesinden saklayan ve ailesinin etiketleyici tutumuyla karşıllaştı̆ıını söyleyen katılımcılarımız da var olmakla birlikte, kişiler bu süreçte çoğunlukla ailelerinden destek gördüklerini ifade etmişlerdir. Ayrıca aile içindeki birinin psikolojik yardım almasının ailenin diğer üyelerinin de damgalanmasına neden olabileceği düşüncesi, bu süreçte yardım alan kişileri olumsuz etkilemektedir.

Psikoloji ve din ilişkisinin kadim ilintisi, insanın derinliklerinin bilinmezliği konusu burada da karşımıza çıkmaktadır. Psikolojik yardım alan bireyler, sosyal çevreleri tarafından en basit haliyle nazar, en karmaşık haliyle cinlere bulaşma gibi inanç ile ilişkilendirilmiş yorumlarla damgalanmışlardır. Burada ilginç olan, psikolojik yardım arama davranışına karşılık olarak sağlık çalışanlarından "sen inançlı insansin senin burada ne işin var" şeklinde bir söylem ile karşılaşanların var olmasıdır. Katılımcılardan din eğitimi veren ve psikolojik yardım alan iki kişinin, sosyal çevreleri tarafindan dini anlamda yetersiz, olgunlaşmamış vb, gibi damgalanmalar yaşamamak için durumlarını kimseyle paylaşamadıkları görülmüştür. Bu durum, toplumda psikolojik yardım alma ile olgunluk düzeyi arasında ters bir ilişkinin varlığını göstermektedir. Katılımcılardan birçoğu, kendilerine neden bu hastalığı yaşıyorum sorusunu sorduklarında, daha çok dini/ manevi hayatlarını sorgulama ve o noktada gerekli gördükleri yerleri düzenleme eğilimlerinin yüksek olduğu görülmüştür.

Toplum nezdinde yaygın bir kullanım olan "Müslüman, depresyona girer $m i$ ? ” söylemiyle karşılaşmış olan katılımcıların çoğu, inanç ile hastalığın birbirine karıştırılmasından şikâyetçidir. Müslümanların da psikolojik rahatsızlığının olabileceğini söyleyen 2 katılımcı peygamberi referans alarak açıklamakta, 3 katılımc ise inancın psikolojik rahatsızlığa sebep olmadığını fakat yardımcı 
güç olduğunu söylemektedir. Katılımcılar bu konunun üzerinde epeyce durarak, bu söylemi bireysel ve sosyal yaşamlarında birçok kez etüt ettiklerini ve bu söylemden son derece rahatsızlık duyduklarını ifade etmişlerdir. Hastalığın inanç eksikliğinden değil, aksine inanç fazlalığından kaynaklanabileceğini söyleyen iki katılımcımız, kişilerin fazla ahlaklı ve dindar olmaya çalıştıklarında bu stresli durumun onları psikolojik yardım arama noktasına taşıyabileceğini söylemesi konuya farklı bir yaklaşım getirmiştir (Ok, 2005).

Damgalamaya etki eden dini faktörler göz önünde bulundurulduğunda, insanın fiziksel ve psikolojik sağlığının yanında manevi olarak da desteklenmesinin önemi ortaya çıkmaktadır. Özellikle hastane içerisinde sunulan manevi danışmanlık hizmeti ve uzmanının bu konudaki katkısının hayati olduğu görülmektedir. Hastalıkların kişi ve toplum tarafindan doğru şekilde yorumlanması, inanç eksikliği olarak damgalanmaması için, psikolojik yardım alma sürecinin manevi danışmanların desteğiyle profesyonel ekip ile sürdürülmesi elzemdir.

Araştırma sonucunda katılımcıların hemen hemen hepsi, manevi danışmanlık hizmetine olumlu bakmıştır. Psikologların kişinin inancıyla ilgili kaygılarını önemsememesi ve ilgilenmemesi ve terapinin inançla bir arada gittiğinde daha çabuk ve bütüncül iyileşme yakalanacağı düşüncesiyle manevi danışmanlığa ihtiyaç olduğunu belirtilmiştir. Öte yandan psikolojik yardım alma süreci ile ilgili olarak önyargı ve damgalamanın önlenmesi için toplumun hastalıklara bakış açısının yeniden inşa edilmesi gerekmektedir. Bu elbette uzun bir süreçtir ancak hasta ve hasta yakınları için uzmanlarca bilgilendirmelerin yapılması bu sürece önemli bir katk1 sağlayacaktır. Bu bilgilendirmeleri yapmak konusunda da manevi danışmanlığa ihtiyaç olduğu bir kez daha ortaya çıkmaktadır.

Günümüzde profesyonel psikolojik yardım alma durumunu olumsuz yönde en çok etkileyen faktör, bu alanda meydana gelen damgalamalardır. The World Health Report'un (2001) sağlık raporlarında konuya genişçe yer verilmiştir. Bu rapora göre, sorunun ortadan kalkabilmesi için sadece psikiyatristlerce değil bu engeli oluşturan tüm sahaların tedavi ekibine dâhil edilmesi gerekmekte, damgalamayla mücadeleyi sağlamada multidisipliner biçimde ruh sağlığını çalışmalarını genişletmek önerilmektedir. Bu disiplinlerden biri insanın hayatını anlamlandırmasında ve sosyal varlığını idame ettirmesinde önemli bir yere sahip olan dini / manevi değerlerdir. Bireylerin dini/manevi hayatına etki eden din eğitiminin sağlıklı bir şekilde yönetilmesi, din görevlilerinin din temelli damgalama konusunda topluma rehberlik etmesi, damgalamayı önleyici girişimler olacaktır. Damgalama ile mücadele uzun zaman isteyen, kolay çözümlenmeyen, 
uzun soluklu ve toplumun her kesimine ulaşılmayı gerektiren bir hizmettir. $\mathrm{Bu}$ çalışma, dini/manevi damgalanma konusunu sahada inceleyen ilk araştırmadır. Probleme kabaca işaret eden sınırlı düzeydeki bu çalışmanın, psikolojik yardım almanın damgalanması ile dini hayat ilişkisi üzerine yapılacak sonraki araştırmalara yön vermesi ve kaynaklık etmesi beklenmektedir. Bu konuda çalışmalar yapılması hem bir ihtiyaç hem de bir sorumluluktur.

\section{Kaynakça}

Al-Krenawi, A. (2005). Socio-political aspect of mental health practice with arabs inthe 1sraeli context, The Israel Journal of Psychiatry And Related Sciences, 42,126-136.

Apaydın H., Özer S., Aydın A. R. (2014). Hastalık sürecinde bireylerin dinî eğilimlerine psikolojik bir yaklaşım. Amasya Üniversitesi Illahiyat Fakültesi Dergisi, 2(3), 5-51.

Atmaca V. (2010). Eski medeniyetlerde günah-hastalık ilişkisi veya Tanrı'nın gazab1 meselesi. Atatürk Üniversitesi İlahiyat Fakültesi Dergisi, 34, 99-121.

Ayten, A. (2010). Tanrı'ya sığınmak -Dinî başa çıkma üzerine psiko-sosyal bir araştırma-. İstanbul: İz.

Ayvaışık, H. B., Er, N. M., Kışlak, Ş. T., Erkuş, A. (2000). Psikoloji terimleri sözlüğü: İngilizce-Türkçe. Ankara: Türk Psikologlar Derneği.

Babaoğlu, A. (2002). Psikiyatri tarihi, İstanbul: Okuyan Us.

Batinic, B., Lemonis, E., Opacic, G. (2013). Effects of internalized stigma of mental disorder on quality of life and self esteem in schizophrenic patients. Schizophrenia, 28.

Baysan-Arabac1, L., Yedikardaşlar-Başoğul, C., Büyükbayram, A. (2015). Adli psikiyatri hastalarının içselleştirilmiş damgalanma ve sosyal işlevsellik düzeyleri. Anadolu Psikiyatri Dergisi, 16(3), 113-121.

Ben-Porath, D. D. (2002). Stigmatization of individuals who receive psychotherapy: an interaction between help-seeking behavior and the presence of depression. Journal of Social And Clinical Psychology, 21(4), 400-413.

Bilge, A. ve Çam, O. (2010). Ruhsal hastalığa yönelik damgalama ile mücadele. TAF Preventive Medicine Bulletin, 9(1), 71-78.

Budak, S. (2000). Psikoloji sözlüğü. Ankara: Bilim ve Sanat.

Çam, M. O. ve Uğuryol, M. (2019). Ruhsal hastalıktan iyileşmeye kültürel etki. Psikiyatride Güncel Yaklaşımlar, 11(1), 55-64. 
Çam, O. ve Bilge, A. (2007). Ruh hastalığına yönelik inanç ve tutumlar. Anadolu Psikiyatri Dergisi, 8, 215-223.

Çam, O. ve Bilge, A. (2013). Türkiye'de ruhsal hastalığa/hastaya yönelik inanç, tutum ve damgalama süreci: Sistematik derleme. Psikiyatri Hemşireliği Dergisi, 4(2), 91-101.

Diyanet İşleri Başkanlığı. (2020). Kur'an-ı Kerim Türkçe meali (2020, Haziran 1) erişim adresi: kuran.diyanet.gov.tr/mushaf

Doğanavşargil, Ö. (2009). Şizofreni ve depresyonda içselleştirilmiş damgalama ve yaşam kalitesi (Yayınlanmamış yüksek lisans tezi). Dokuz Eylül Üniversitesi Sağlık Bilimleri Enstitüsü, İzmir.

Eker, D. (1989). Attitudes toward mental illness: Recognition, desired social dislance, expected hürden and negative influence on mental health among Turkish freshmen. Social Psychiatry and Psychiatric Epidemiology, 24(3), 146-150.

Eker, F., Öner, Ö, Şahin, S. (2010). Din görevlilerinin şizofreniye ilişkin bilgi ve tutumları (Düzce örneği). Psikiyatri Hemşireliği Dergisi, 1(2), 63-70.

Ekşi, H. (2001). Başaçıkma, dini başaçıkma ve ruh sağlı̆̆ı arasındaki ilişki üzerine bir araştırma: Ĕ̆itim, ilahiyat ve mühendislik fakültesi öğrencilerinin karşılaştırılması (Yayınlanmamış doktora tezi). Marmara Üniversitesi Sosyal Bilimler Enstitüsü, İstanbul.

Ersoy, M. A. ve Varan, A. (2007). Ruhsal hastalıklarda içselleştirilmiş damgalanma ölçeği Türkçe Formu'nun güvenilirlik ve geçerlik çalışması. Türk Psikiyatri Dergisi, 18(2), 163-171.

Foucault, M. (2013). Akıl hastalı̆̆l ve psikoloji (E. Bayoğlu, Çev.). İstanbul: Ayrıntı.

Gargari, S. (2015). Dokuz Eylül Üniversitesi’nde öğrenim gören üç farkll fakülte ögrencilerinin alkol ve madde bağımlılı̆̆ına yönelik damgalamaları (Yayınlanmamış yüksek lisans tezi). Ege Üniversitesi Sağlık Bilimleri Enstitüsü, İzmir.

Geçtan, E. (2012). Psikodinamik psikiyatri ve normaldışı davranışlar. İstanbul: Metis.

Goffman, E. (1963). Stigma: Notes on the management of spoiled identity. ABD, Prentice-Hall, Inc.

Goffman, E. (2018). Damga: Örselenmiş kimliğin idare edilişi üzerine notlar. Ankara: Heretik.

Göcen, G. (2015). Tüp bebek tedavisi almış kadınların dinî başa çıkma süreçleri ve dinî yaşantılar üzerine nitel bir araştırma. İstanbul Üniversitesi İlâhiyat Fakültesi Dergisi, 32, 165-217.

Gökengin, D., Çalık, Ş., Öktem, P. (2017). Türkiye'de HIV'le ilgili damgalama ve ayrımcılığın analizi: HIV'le yaşayan kişiler için damgalanma göstergesi sonuçları. Klinik Dergisi, 30(1), 15-21. 
Güngörmüş, K., Ekinci, M., Daş, M. (2014). İlahiyat fakültesi öğrencilerinin ruhsal hastalığa yönelik inançlarının belirlenmesi. Hemşirelikte Eğitim ve Araştırma Dergisi, 11(2), 45-51.

Hayward, P., Wong, G., Lam, D. (2002). Stigma and selfesteem in manic depression: An exploratory study. Journal of Affect Disorders, 69, 61-7.

Horozcu, Ü. (2010). Tecrübî araştırmalar 1şığında dindarlık ve maneviyat ile ruhsal ve bedensel sağlık arasındaki ilişkisi. Milel ve Nihal İnanç, Kültür ve Mitoloji Araştırmaları Dergisi, 7(1), 209-240.

İz, F., Hony, H. C., Alderson, A. D. (1989). Ingilizce Türkçe sözlük = The Oxford English Turkish Dictionary. İstanbul: ABC Kitabevi.

Kapıkıran, N. A. ve Kapıkıran, Ş. (2013). Psikolojik yardım aramada kendini damgalama ölçeği: Geçerlik ve güvenirlik. Türk Psikolojik Danışma ve Rehberlik Dergisi, 5(40), 131-141.

Kaya, Y. ve Ünal, S. (2006). Psikotik bir hastalık durumunu açıklama ve çare arama davranışında cinsiyetin rolü. Anadolu Psikiyatri Dergisi, 7, 197-203.

Kula, N. (2005). Bedensellik engellilik ve dini başa çıkma. İstanbul: DEM.

Kuş- Saillard, E. (2010). Ruhsal hastalara yönelik damgalamaya ilişkin psikiyatrist görüşleri ve öneriler. Türk Psikiyatri Dergisi, 21(1), 14-24.

Link, B. G., Struening, E. L., Neese-Todd, S., Asmussen, S., Phelan, J. C. (2001). Stigma as a barrier to recovery: The consequences of stigma for the selfesteem of people with mental illnesses. Psychiatric Services, 52, 1621-1626.

Oban, G., Küçük, L. (2011). Ergenlerde ruhsal hastalıklara yönelik damgalamayı etkileyen etmenler. Psikiyatri Hemşireliği Dergisi, 2(1), 31-39.

Ok, Ü. (2005). Dini düşüncede yaşanan stresin (şüphe, uyumsuzluk, çelişki v.b.) boyutları. Dini Araştırmalar, 8(22), 11-40.

Oran, N. T., Şenuzun, F. (2008). Toplumda kırılması gereken bir zincir: HIV/AIDS stigması ve baş etme stratejileri. Uluslararası Insan Bilimleri Dergisi, 5(1), 1-16.

Özmen, E. ve Taşkın, E. O. (2004). Ruhsal hastalıklara yönelik tutumların ruh sağlığı hizmetlerine etkisi. Psikiyatri Psikoloji Psikofarmakoloji (3P) Dergisi, 12 (Ek-3), 83-92.

Reber, A. S, (1985). The penguin dictionary of psychology, penguin books, London, XI.

Sezer, S., GÜLLEROĞLU, D. (2016). Psikolojik yardım arama tutumlarını yordayan değişkenler: Kendini damgalama, özsaygı, psikolojik yardım almış olma. Uludă̆ Üniversitesi Ĕ̈itim Fakültesi Dergisi, 29(1), 75-93.

Stanford, M. S. (2007). Demon or disorder: A survey of attitudes toward mental illness in the christian church. Mental Health, Religion, Culture, 10(5), 445-449. 
Subaşı, Z. (2016). Cinsel sorunlarda manevi danışmanlık ve rehberlik (MDR) uygulamaları. A. Ayten, M. Koç, N. Tınaz (Ed.), Manevi danışmanlık ve rehberlik Cilt-I İçinde (s. 191-231). İstanbul: Dem.

Taşkın, E. O. (2007). Ruhsal hastalıklara yönelik tutumlar ve damgalamayı etkileyen faktörler. E. Oryal Taşkın (Ed.), Stigma: Ruhsal hastalıklara yönelik tutumlar ve damgalama içinde (s. 41-57). İzmir: Meta Basım.

The World Health Report, Mental Health: New Understanding, New Hope. (2001). Chapter 3: Solving Mental Health Problems (2019, Mayıs 9). Erişim adresi: www.who.int

Topkaya, N. (2014). Psikolojik yardım almaya ilişkin tutumu yordamada cinsiyet, psikolojik yardım alma nedeniyle kendini damgalama ve sosyal damgalanma. Educational Sciences: Theory, Practice, 14(2), 471-487.

Türk Dil Kurumu, “Damga”, Erişim adresi: http://tdk.gov.tr

Varas-Diaz, N., Neilands, T.B., Malavé Rivera, S., Betancourt, E. (2010). Religion and HIV/AIDS stigma: Implications for health professionals in Puerto Rico. Glob Public Health, 1-18.

Vogel, D. L, Wade, N.G., Ascheman, P. L. (2009). Measuring perceptions of stigmatization by others for seeking. psychological help: Reliability and validity of a new stigma scale with college students. Journal of Counseling Psychology, 56(2), 301-308.

Vogel, D. L., Wade, N. G., Hackler, A. H. (2007). Perceived public stigma and the willingness to seek counseling: The mediating roles of self stigma and attitudes toward counseling. Journal of Counseling Psychology, 54, 40-50.

Vogel, D. L., Wade, N. G., Haake, S. (2006). Measuring the self-stigma associated with seeking psychological help. Journal of Counseling Psychology, 53, 325-337.

Vogel, D., Bitman, R. L, Hammer, J. H., Wade, N. G. (2013). Is stigma 1nternalized? The longitudinal impact of public stigma on self-stigma. Journal of Counseling Psychology, 60(2), 311-316.

Yüksel, G. E. ve Taşkın, E. O. (2005). Türkiye'de hekimler ve tıp fakültesi öğrencilerinin ruhsal hastalıklara yönelik tutum ve bilgileri. Anadolu Psikiyatri Dergisi; 6, 113-21. 
Extended Abstract

\section{The Religious/Spiritual Stigmatization of Receiving Psychological Help, and the Expectations of People Who Go Through this Process from Spiritual Counseling Services}

Kevser ÇAĞLAN, Ph.D. Student.

İstanbul University, Social Sciences Institute, Turkey.

caglankevser@gmail.com

http://orcid.org/0000-0002-5638-5013

Gülüşan GÖCEN, Corresponding Author, Associate Professor.

İstanbul University, Faculty of Theology, Turkey.

gulusan.gocen@istanbul.edu.tr

http://orcid.org/0000-0003-4856-9653

Article Type: Research Article

https://doi.org/10.34234/ded. 617263

Received Date: 09.09.2019

Accepted Date: 26.05 .2020

Published Date: 25.06 .2020

\section{Introduction}

Stigmatization is disfavoring a person by means of negative judgment and social exclusion (Çam and Bilge, 2013; Goffman, 2018: 27). Individuals can be stigmatized by their social environment through exclusion, alienation and discrimination as well as self-stigmatizing (Vogel et al. 2006; Baysan- Arabac1, 2015:114-115; Sezer and Gülleroğlu, 2016). All psychological disorders have been the subject of stigma and discrimination since the early ages (Çam and Bilge, 2007). People receiving psychological help stigmatized with attributions such as "crazy, sick", etc. (Foucault, 2013). In addition to these, people are seen to be judged in terms of their religiosity/spirituality in religious circles (Al-Krenawi 2005; Diaz et al., 
2010; Eker et al., 2010; Güngörmüş et al., 2014). Stigma prevents individuals from applying to health services by damaging their social status and self-esteem (Link et al., 2001; Batinic et al., 2013). Thus, it causes conflicts both within themselves and within their social lives (Hayward et al., 2002; Yüksel and Taşkın, 2005). This study that examines the aforementioned problem in the context of religion and psychology, is important in terms of yielding the role of spiritual counseling and guidance in solving the stigma problem.

\section{Aim of the Research}

This study aims to examine the problems arising from the religious/spiritual stigma experienced by people receiving psychological help, and to make explanations and suggestions about the role of spiritual counseling service in solving these problems. The research questions are as follows:

- How do individuals receiving psychological help evaluate themselves in terms of religion?

- What kind of religious/spiritual explanations and suggestions do individuals face from their family and social environment during this process?

- How do these individuals evaluate spiritual counseling and what are their views on its role?

\section{Method}

\section{Research Design}

The research is designed as a qualitative case study. Phenomenological approach was used in this study. Phenomenology is an in-depth study and explanation of a phenomenon we have previously learned in a real context (Yildirım and Şimşek, 2016: 69). From purposeful sampling methods, snowball sampling, criterion sampling and maximum diversity sampling are used in this study. Accordingly, the study group consists of volunteer and religious participants who have received professional psychological help for at least two months.

\section{Data Collection and Analysis}

The data were collected in April 2019. The data collection tools are interview and observation. Semi-structured interview technique was used in the resear- 
ch. The interviews were recorded, then transcribed and analyzed. The participants were referred to by numbers instead of names, by assigning numbers to each participant. In this way, their identities were kept anonymous. Descriptive analysis method was used to analyze the data. In descriptive analysis, the data are presented and interpreted in accordance with previously determined themes (Yıldırım and Şimşek, 2016: 239). In addition to the detailed descriptions, direct quotations were frequently included. The findings were interpreted with support of the researcher's observations.

\section{Findings}

People who are getting psychological help are stigmatized regarding the cause and the treatment of their illness in their social environment, and being labelled like; "with an evil eye", or who "lost his marbles (being infected with a jinni)", or "distrustful", "unconscious" or "ungrateful", etc. Suggestions such as increasing the prayers, turning to Allah, refreshing their faith, and not hindering themselves from worships were made to those who are getting help. In this process, people also met some doctors who thought that they should be conscious and strong and therefore healthy because of the fact that they were Muslims. This shows that, healthcare personnel, as well as patients, should be supported in terms of psychological diseases and stigmatization. As stated in many studies, some health workers cannot evaluate psychological diseases without leaving their social judgment aside (Kuş-Saillard, 2010).

It was determined that the majority of the participants experienced religiously/spiritually interiorized stigma. These can be classified under three categories; a) being punished for a sin they committed, b) Allah is reminding them of Himself, so that to discipline them, c) experiencing the illness as a result of disruptions of their worship, and weariness in their faith. The view that, diseases are given as a punishment for sins, is quite common among religious people. As a matter of fact, according to researches, that when individuals first encounter illnesses, instead of treatment medical they turn to faith and worship, increase their prayer/ worship and repent in order to get rid of the disease (Apaydın et al., 2008; Kula, 2005; Göcen, 2015).

As for the problem question, "Does the faithful people get depressed?", it has been observed that individuals mostly refer to the troubles experienced by the Prophet, and emphasize that human beings are mortal, and their psycho- 
logy may be impaired. In the findings regarding the role of spiritual counseling, spiritual support is needed with the correct interpretation and execution of the assistance to people seeking psychological treatment without stigmatization. It was also found that, people in the process of getting help needed spiritual support to share their concerns about their belief, and get their religious inquiries answered by the help of a counselor, and repair the perception regarding experiencing psychological problems. The expectations of the participants from the spiritual counseling service are as follows: a) consultants are not to be biased and stigmatizing, b) they should be insightful and valuing, not judging, c) Not being condemning, manipulative and compelling in religious matters, d) Using a language directly based on the person's condition, e) Supporting not only the patient but also their families in this process.

\section{Conclusion, Discussion and Suggestions}

Whether or not being subjected to stigmatization, getting psychological help is a difficult process. As a matter of fact, the number of participants who do not feel any shame and need to hide in the help-getting process is very low. This indicates that the social stigmatizing attitude towards the psychological disorders is quite high. Especially, religious people's evaluation of psychological disorders as related to the weakness of the individual's faith stigmatize them religiously and spiritually. Most of the participants faced with this widely-used expression, “Does Muslim ever get depressed?". However, participants complain about the misrelating of belief and psychological disorder in this regard.

A significant number of participants are being self-stigmatized religiously/ spiritually, even if they didn't experience stigmatization by the society. Looking at the overall religious coping researches, it is seen that negative religious coping styles are often used by religious people (Ayten, 2010; Ekşi, 2001). Stigmatization and negative religious coping are two intertwined issues. The fact that individuals have a belief-based negative approach in evaluating diseases can also be considered as negative religious coping (Babaoğlu, 2002; Ok, 2005; Geçtan, 2012). Therefore, faith-based stigmatization can be found in researches dealing with negative religious coping studies (Atmaca, 2010). However, it is important and necessary to clarify the boundaries between these two issues. Negative religious coping is a method used by the individual to overcome the situation in the process of getting help. But stigmatization is about an individual 
that being judged, but nevertheless seeking help, and most importantly, he or she feels unhappy about this judgment. On the other hand, in order to prevent stigmatization, perspective of the society on psychological diseases must be reconstructed. Spiritual expert support that provided for patients and their relatives will make an important contribution to this process. 